JURNAL ILMIAH MANAJEMEN DAN KEWIRAUSAHAAN Vol 1,No.1, Mei 2021, pp. 51 - 86

p-ISSN : 2808-876X (print)

e-ISSN : 2798-1312 (online)

http://journal.politeknik-pratama.ac.id/index.php/IMK

page 51

\title{
DESAIN KOMUNIKASI VISUAL SEBAgai STRATEgI PERANCANGAN PROMOSI TOKO PANCING INDO RAYA DI SEMARANG
}

\author{
${\text { Febryantahanuji Febryantahanuji }{ }^{1} \text {, Haryo Kusumo }{ }^{2} \text {, Hendri Rasminto }}^{3}$ \\ ${ }^{1}$ Universitas Stekom, email : febryan@stekom.ac.id \\ ${ }^{2}$ Universitas Stekom, email : haryo@ @stekom.ac.id \\ ${ }^{3}$ Universitas Stekom, email : hendri@stekom.ac.id
}

\section{ARTICLE INFO}

Article history:

Received 28 April 2021

Received in revised form 5 Mei 2021

Accepted 20 Mei 2021

Available online 1 Juni 2021

\section{ABSTRACT}

Nowadays many companies, shops and home industries need promotional media to be known by the wider community. Many promotional media are used to promote a company or product being sold, one of which is brochures, stickers, banners and x-banners. For a company or store that offers its products, brochures, stickers, banners and x-banners serve as promotional media so that people are more familiar with the products being sold and know the latest information related to the promotion of the store or company.

One such company or store is the Indo Raya Fishing Shop. Indo Raya Fishing Shop, located in the city of Semarang, is engaged in the sale of fishing equipment and other supporting accessories. In this case, Toko Pancing Indo Raya wants to promote the goods sold in its store and the latest information, which previously only sold wholesale, can now buy in retail or individually. From this problem, the author uses the interview method, namely the author conducts direct talks with the Indo Raya Fishing Shop and the author's observations go directly to the field to find the data needed.

Making designs based on existing theories and using design principles and then processing them with computer programs such as Adobe Photoshop Cs3 and Corel Draw X4.

Keywords : DKV, Strategi Promosi

\footnotetext{
Abstrak

Sekarang ini banyak perusahaan, toko dan home industri membutuhkan media promosi agar dikenal oleh masyarakat luas. Banyak media promosi yang digunakan untuk mempromosikan suatu perusahaan atau produk yang dijual, salah satunya dengan media brosur, stiker, spanduk dan x-banner. Untuk sebuah perusahaan atau toko yang menawarkan produknya, brosur, stiker, spanduk dan x-banner berfungsi sebagai media promosi agar masyarakat lebih mengenal produk yang dijual dan tahu akan informasi - informasi terbaru yang berkaitan dengan promosi toko atau perusahaan tersebut.

Salah satu perusahaan atau toko tersebut adalah Toko Pancing Indo Raya. Toko Pancing Indo Raya yang berada di kota Semarang ini bergerak pada bidang penjualan alat - alat memancing dan aksesoris pendukung lainnya. Dalam hal ini Toko Pancing Indo Raya ingin mempromosikan barang yang dijual di tokonya dan informasi terbaru yang sebelumya hanya menjual dalam bentuk grosir kini bisa membeli dalam bentuk eceran atau satuan. Dari masalah tersebut penulis menggunakan metode interview yaitu penulis melakukan pembicaraan langsung kepada pihak Toko Pancing Indo Raya dan observasi penulis terjun langsung kelapangan untuk mencari data - data yang dibutuhkan.

Pembuatan desain berdasarkan teori - teori yang sudah ada dan menggunakan prinsip - prinsip desain kemudian mengolahnya dengan program komputer seperti Adobe Photoshop Cs3 dan Corel Draw X4.

Keywords : DKV, Strategi Promosi

\section{Pendahuluan}

Di era globalisasi sekarang ini yang semakin modern, banyak sekali terdapat bebagai macam jenis usaha kecil maupun besar yang berkembang, salah satunya yaitu usaha toko pancing yang ada di semarang umumnya toko pancing yang menjual peralatan memancing guna menunjang setiap kebutuhan para pemancing. Di kota semarang pun tidak sedikit toko yang menjual peralatan memancing baik itu penjual
} 
kecil atau besar, ini juga akan membuat persaingan dalam usaha semakin ketat. Setiap usaha yang didirikan mempunyai tujuan yakni melayani konsumen dengan baik serta bekerja secara efisien dan memberikan kepuasan kepada konsumennya sehingga usaha yang didirikan mendapat kepercayaan kepada konsumen dan selalu membeli barang - barang yang dijual.

Dari berbagai usaha kecil yang ada di Semarang yakni salah satunya adalah Toko Pancing Indo raya beralamat di Jalan Ronggowarsito No.7 Semarang, yang bergerak di bidang penjualan alat memancing yang meliputi penjualan alat memancing, aksesoris pendukung untuk memancing, umpan ikan pelet maupun tiruan, jaring dan lain - lain. Sebelumnya toko pancing ini menjual hanya khusus untuk grosir namun sekarang toko ini juga dapat menjualkan untuk umum yaitu boleh membeli dalam satuan atau kecil, dan masih banyak produk baru yang ditawarkan, hal ini bertujuan untuk menambah pemasukan yang lebih banyak bagi toko Pancing Indo raya. Setelah melakukan tanya jawab kepada pemilik toko penulis menemukan beberapa masalah yang dihadapi toko pancing yaitu masih banyak masyarakat yang belum mengetahui jika toko tersebut kini sudah bisa menjualkan dagangannya untuk umum dalam bentuk satuan.

Masalah ini timbul karena kurangnya informasi atau promosi dari Toko Pancing Indo Raya. Hal ini mengakibatkan pendapatan Toko Pancing Indo Raya dari penjualan selama ini masih dikatakan kurang untuk skala toko besar seperti Toko Pancing Indo Raya. Selain kurangnya promosi dalam kurun waktu dua tahun terakhir ini toko pancing mengalami naik turun pemasukan terutama di musim kemarau hanya mendapatkan kisaran sepuluh juta kebawah karena sedikitnya pemancing yang mencari ikan di musim kemarau,namun pada saat musim penghujan pemasukan toko mengalami kenaikan. Toko Pancing Indo Raya saat ini hanya menggunakan spanduk yang dipasang didepan toko saja sehingga banyak masyarakat luas yang belum mengetahui akan informasi tersebut. Oleh karena itu, penulis ingin membantu memecahkan masalah yang dihadapi Toko Pancing Indo Raya . Dalam hal ini , penulis menggunakan media cetak yang akan mempermudah masyarakat untuk mengetahui Toko Pancing Indo Raya. Salah satu media cetak yang digunakan adalah x-banner, spanduk, brosur, dan stiker.

Spanduk adalah media cetak yang dapat dibaca dengan teliti iklannya, dapat dibaca kembali bagian yang dikehendaki serta dapat dilihat dari jarak jauh. Keunggulan dari media cetak lain seperti brosur, stiker, dan x-banner adalah media ini sangatlah sederhana dan langsung tepat sasaran. Dalam teknik promosi sendiri akan dilakukan penyebaran secara langsung yaitu saat konsumen membeli atau berkunjung di Toko Pancing Indo Raya langsung diberikan stiker, sedangakan untuk brosur sendiri Toko Pancing Indo Raya akan memperkerjakan seseorang untuk membagikan brosur tersebut. X-banner akan dipasang di depan Toko Pancing Indo Raya begitu juga dengan spanduk yang dipasang di depan toko dan dipasang di jalan. Diharapkan setelah promosi yang dilakukan ini akan menambah pendapatan serta konsumen untuk Toko Pancing Indo Raya.

Berdasarkan masalah dari kejadian yang sudah dijelaskan diatas mengenai sistem promosi, penulis mencoba membuat rancangan promosi Toko Pancing Indo Raya dalam Tugas Akhir ,dengan judul "DESAIN KOMUNIKASI VISUAL SEBAGAI STRATEGI PERANCANGAN PROMOSI TOKO PANCING INDO RAYA DI SEMARANG “.

\section{LANDASAN TEORI}

\section{Desain Komunikasi Visual}

Desain komunikasi visual yaitu seni menyampaikan pesan (arts of communication) dengan menggunakan bahasa rupa (visual language) yang disampaikan melalui media berupa desain yang bertujuan menginformasikan, mempengaruhi hingga merubah perilaku audience sesuai dengan tujuan yang ingin diwujudkan. Sedangkan bahasa rupa yang dipakai berbentuk grafis, tanda, symbol, ilustrasi gambar atau foto, tipografi. Desain Komunikasi Visual terdiri dari tiga kata yaitu : (supriyanto, 2010)

2.1. Desain

Desain diambil dari kata "designo" (itali) yang artinya gambar, sedangkan dalam bahaa inggris desain diambil dari bahasa latin (designare) yang artinya merencanakan atau merancang. Dalam dunia seni rupa istilah desain dipadukan dengan reka bentuk, reka rupa, rancangan atau seketsa ide. (supriyanto, 2010) 


\subsection{Komunikasi}

Komunikasi berarti menyampaikan suatu pesan dari komunikator (penyampai pesan) kepada komunikan (penerima pesan) melalui suatu media dengan maksud tertentu. Komunikasi sendiri berasal dari bahasa inggris communication yang diambil dari bahasa latin "communis" yang berarti "sama", kemudian komunikasi dianggap sebagai proses menciptakan suatu kesamaan atau suatu kesatuan pemikiran antara pengirim dan penerima. (supriyanto, 2010)

2.3. isual

Visual bermakna segala sesuatu yang dapat dilihat dan direspon oleh indera penglihatan yaitu mata. Berasal dari kata latin "videre" yang artinya melihat yang kemudian dimasukan kedalam bahasa inggris yaitu "visual". (supriyanto, 2010)

\section{METODE PENELITIAN}

Untuk mengumpulkan data-data sebagai bahan penyusunan Tugas Akhir ini, penulis menggunakan beberapa metode pengumpulan data, yang meliputi :

1) Interview

Penulis melakukan pembicaraan langsung kepada pihak Toko Pancing Indo Raya untuk memperoleh data.

2) Observasi

Penulis terjun langsung kelapangan untuk mencari data - data yang dibutuhkan.

\section{HASIL DAN PEMBAHASAN}

\section{1 pembuatan Desain Brosur Bagian Depan.}

a. Langkah pembuatan desain brosur bagian depan :

(1). Buka software Adobe Photoshop Cs3

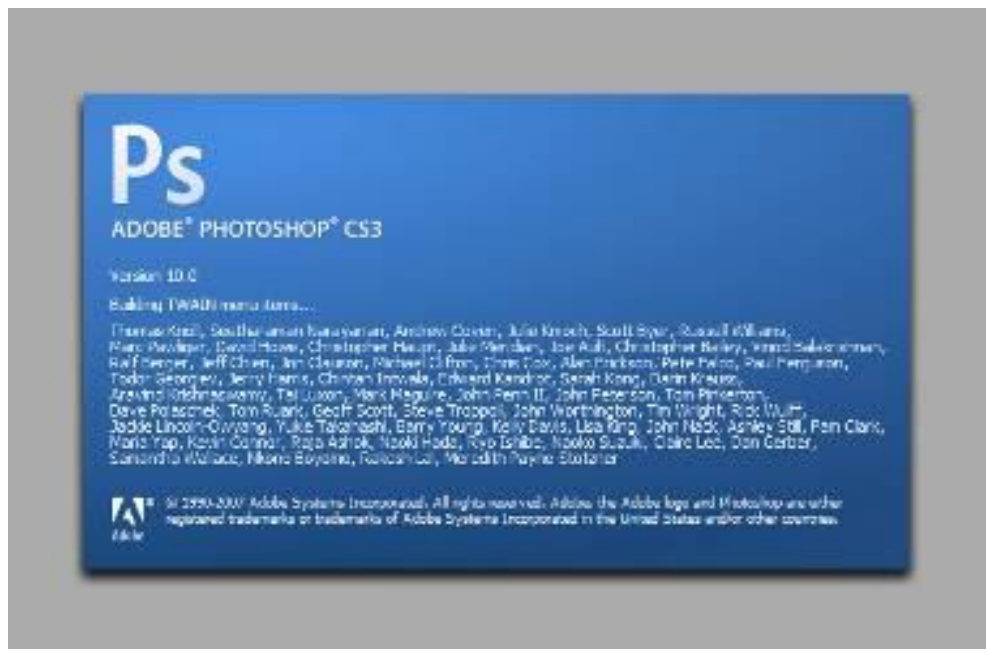

Gambar 4. 28 Membuaka software Adobe Photoshop.

(2). Klik file - new lalu atur ukuran layout width $15 \mathrm{~cm} \times$ Height $20 \mathrm{~cm}$ dengan resolusi 200pixel. 
55

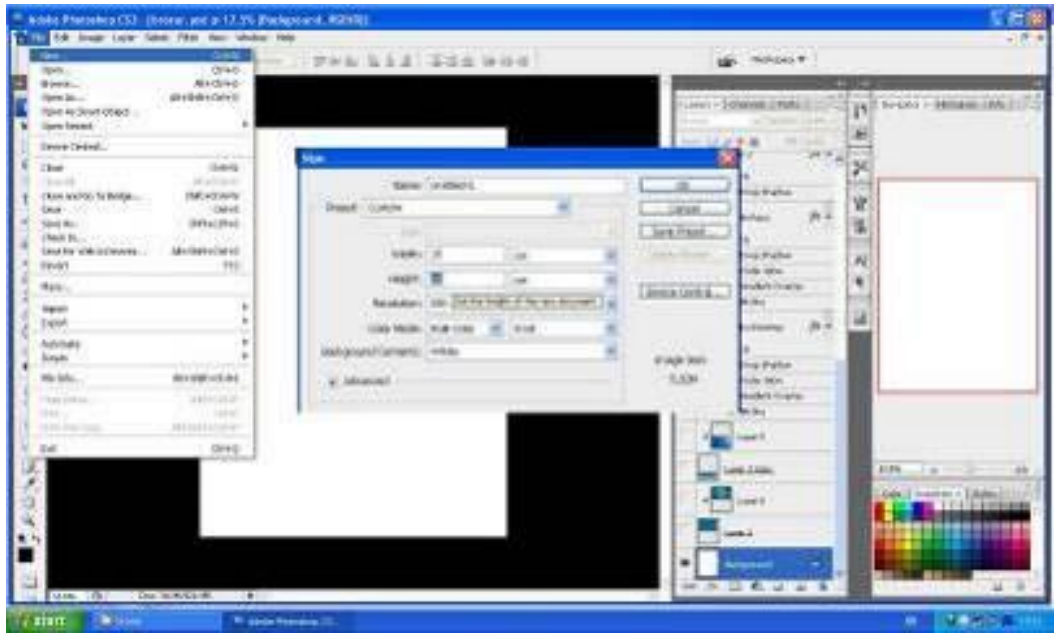

Gambar 4. 29 Langkah membuat layout baru.

(3). Langkah selanjutnya membuka file background yang akan dipakai untuk background dengan cara, klik file - open lalu pilih gambar background yang akan dipakai.

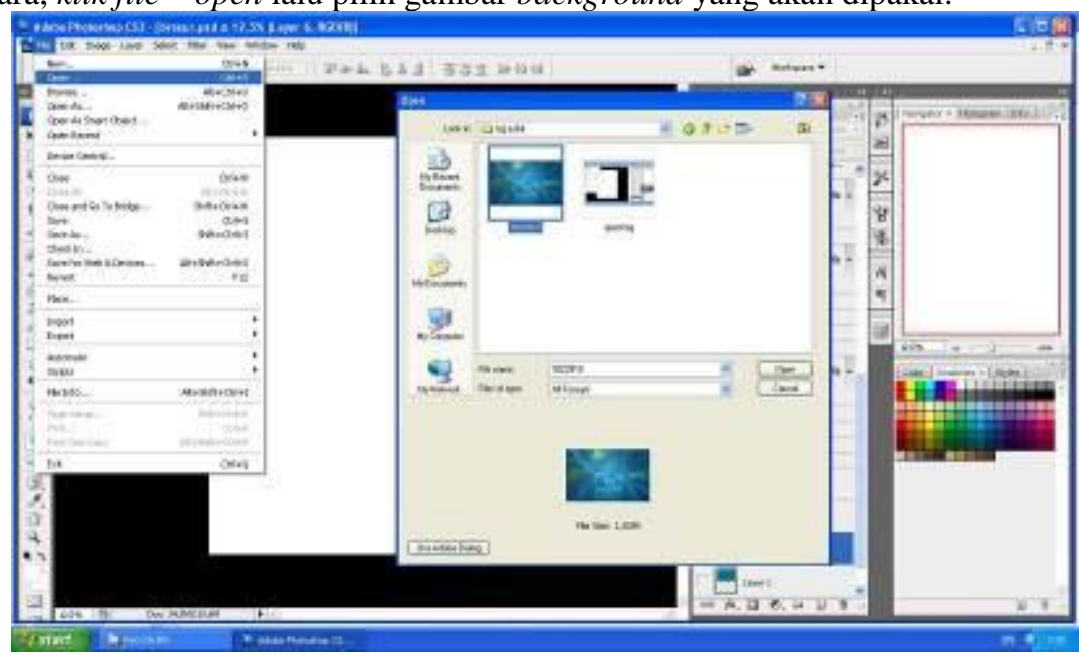

Gambar 4. 30 Membuka file Background.

(4). Setelah background dipilih langkah selanjutnya yaitu memasukan background ke dalam layout dengan cara klik Move Tool lalu tarik atau drag background ke dalam layout dan atur background supaya terlihat rapi.

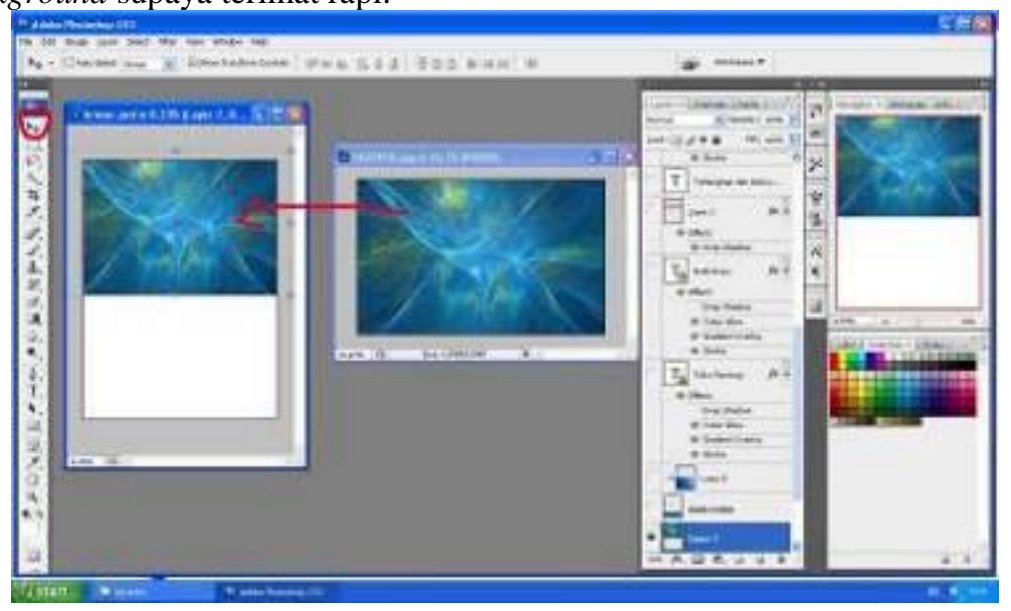

Gambar 4. 31 Memasukan background ke layout. 
(5). Tahap selanjutnya memasukan nama toko yang sudah jadi ke dalam layout dengan cara masukan file nama toko yang sudah jadi setelah itu tarik file nama toko ke dalam layout menggunakan move tool seperti contoh dibawah berikut ini.

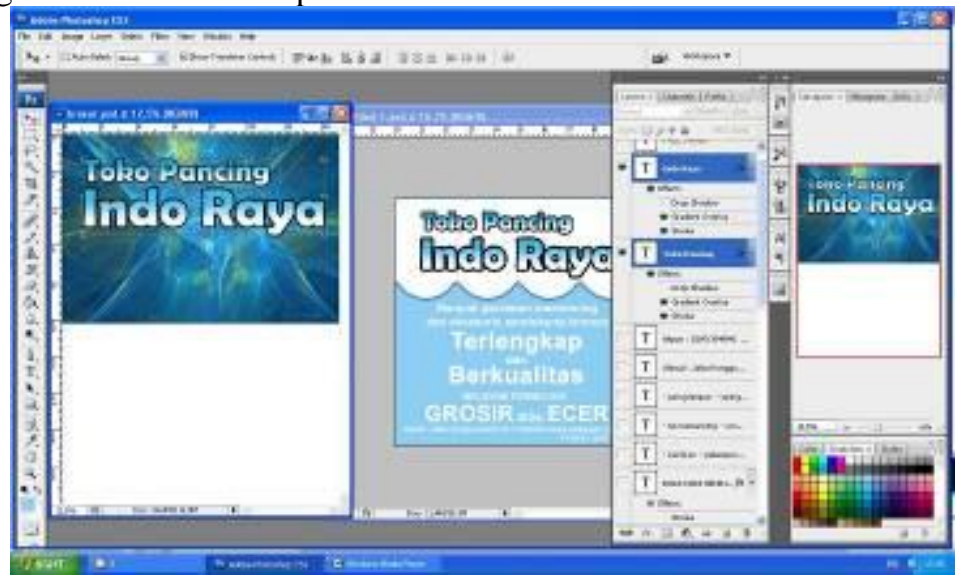

Gambar 4. 32 Memindahkan file nama toko yang sudah ada.

(6). Langkah selanjutnya yaitu memberi efek Outner Glow pada text nama toko dengan cara klik add a layer style - Outner Glow lalu atur opacity 68\%, Spread 31\%, Size 133px, Range 50\%.

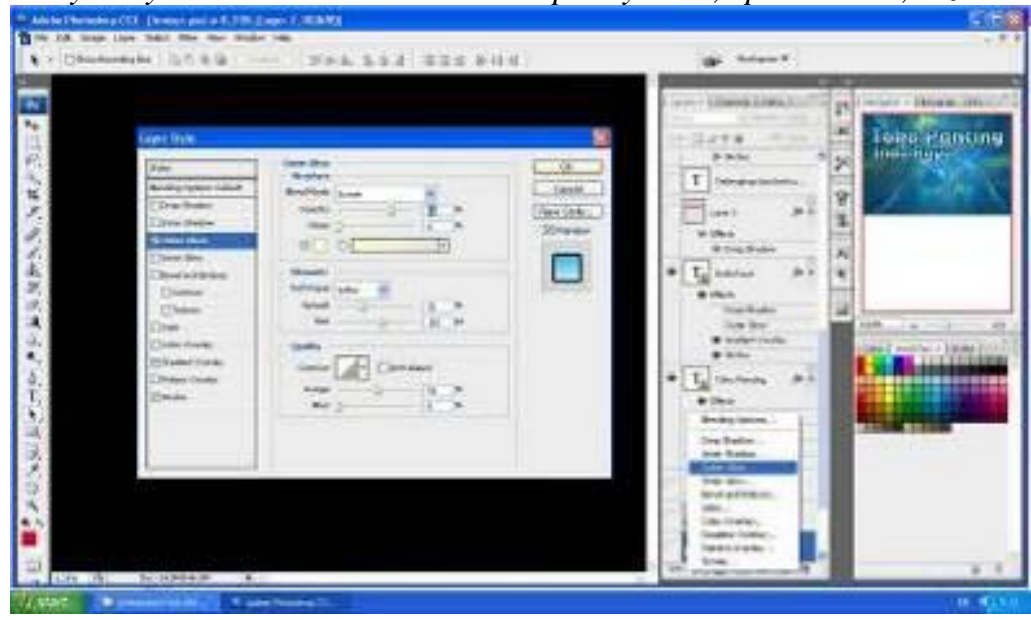

Gambar 4. 33 Mengatur Outner Glow.

(7). Selanjutnya yaitu ketik text "Terlengkap dan berkualitas" dengan menggunakan font Arial selanjutnya memberi background text persegi dengan cara membuat layer baru create a new layer lalu pilih Rectanguler Marquee Tool lalu tarik agar membentuk persegi yang terseleksi.

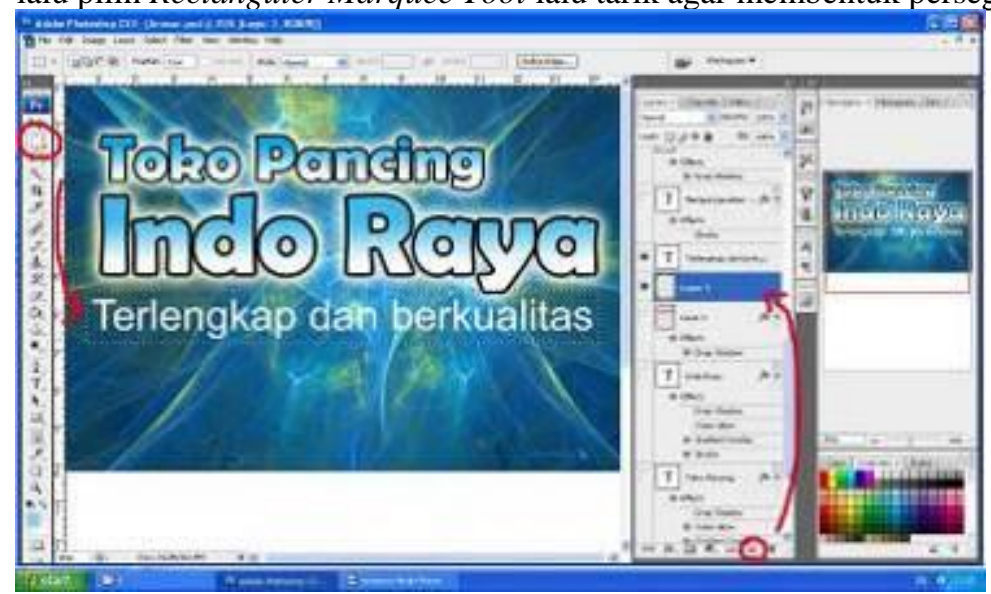

Gambar 4. 34 background dengan Rectanguler Marquee Tool. 
57

(8). Setelah kotak terbentuk langkah selanjutnya beri warna merah pada background, merah melambangkan menarik sehingga diharapkan bisa menarik pembeli untuk membeli di toko, pilih Set Foreground color - Paint Bucket Tool - klik Paint Bucket Tool ke dalam kotak yang telah terseleksi.

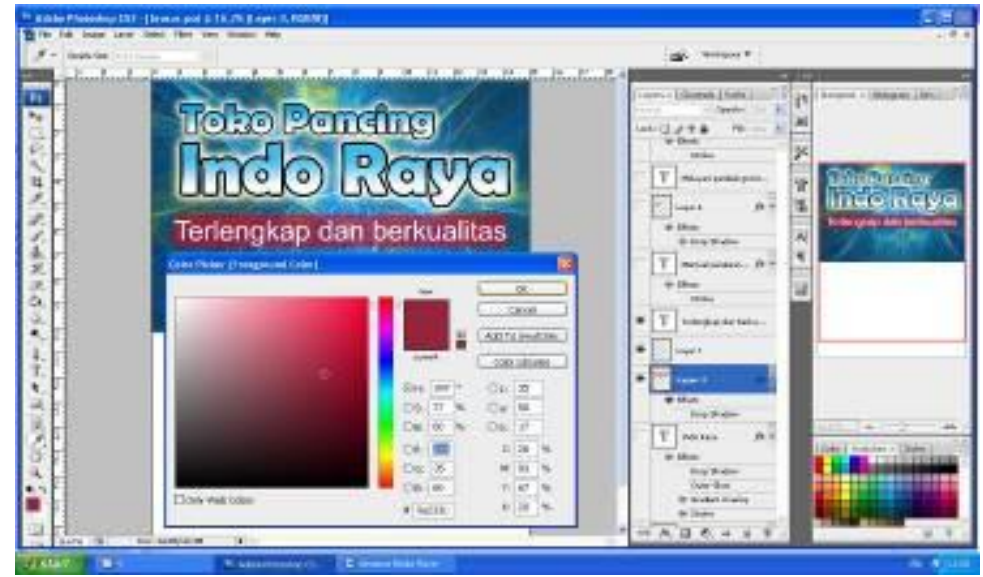

Gambar 4. 35 Memberi warna background text.

(9). Langkah berikutnya memberi efek Drop Shadow pada background text dengan cara klik Add a layer style - pilih Drop Shadow lalu atur Drop Shadow opacity 75\%, Angle 120 derajat, Distance 19px, Spread 2\%, Size 0px.

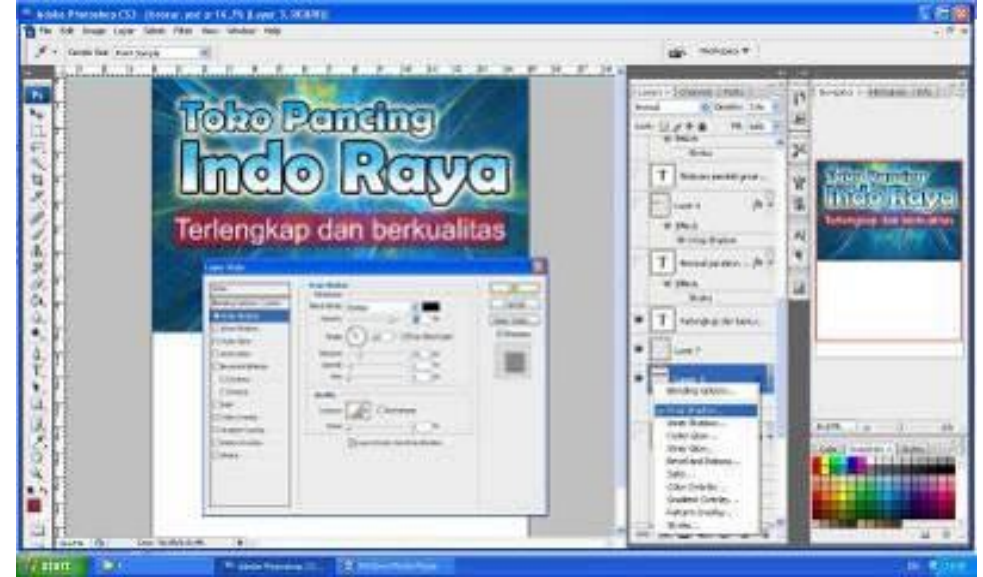

Gambar 4. 36 Memberi efek Drop Shadow.

(10). Tahap berikutnya adalah mengetik text " melayani pembeli grosir atau ecer " yang menggunakan tipe text arial dengan cara klik Horizontal Type Tool lalu pilih tipe font dan ketik text.

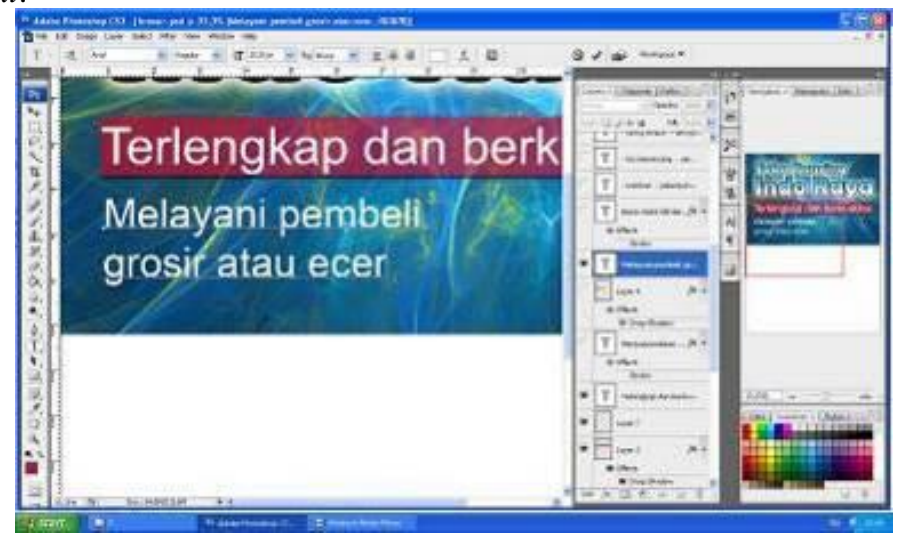

Gambar 4. 37 Mengetik text " Melayani pembeli grosir atau ecer”. 
(11). Berikutnya setelah text diketik lalu membuat background text berbentuk persegi empat dengan cara klik Create a new layer untuk menambahkan layer baru stelah itu klik Rectengular marquee tool lalu klik pada layout lalu tahan dan geser agar terseleksi membentuk persegi empat.

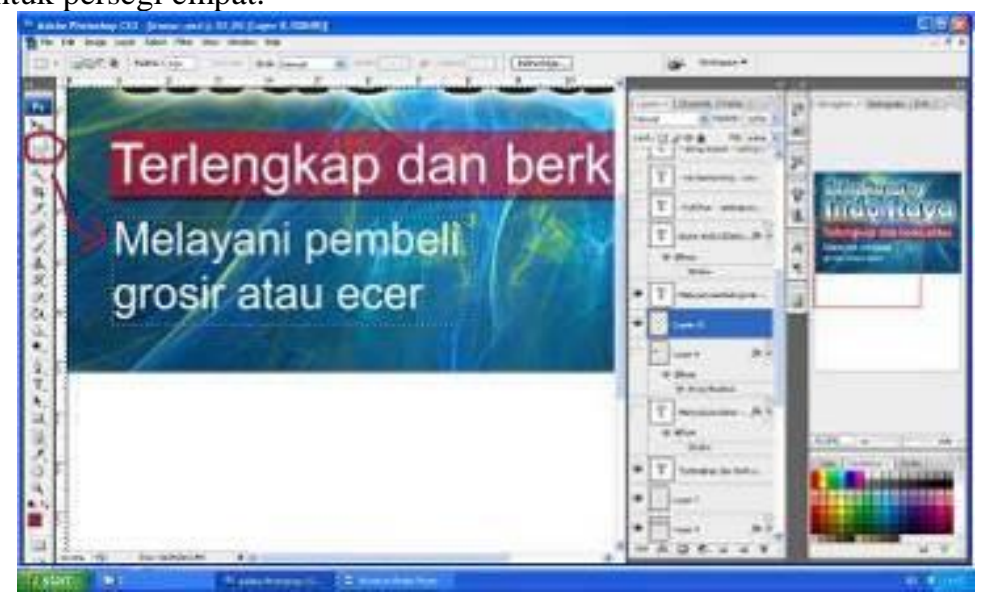

Gambar 4. 38 Membuat background Rectengular marquee tool.

(12). Tahap selanjutnya memberikan warna pada background persegi empat klik set foreground color lalu pilih warna orange dipilihnya warna orange karena melambangkan kebahagiaan diharapkan pembeli di Toko Pancing Indo Raya bisa bahagia dan terus membeli produk yang di jual di Toko Pancing Indo Raya. Setelah warna dipilih klik Paint Bucket Tool dan klik kiri untuk menuangkan warna ke objek persegi empat.

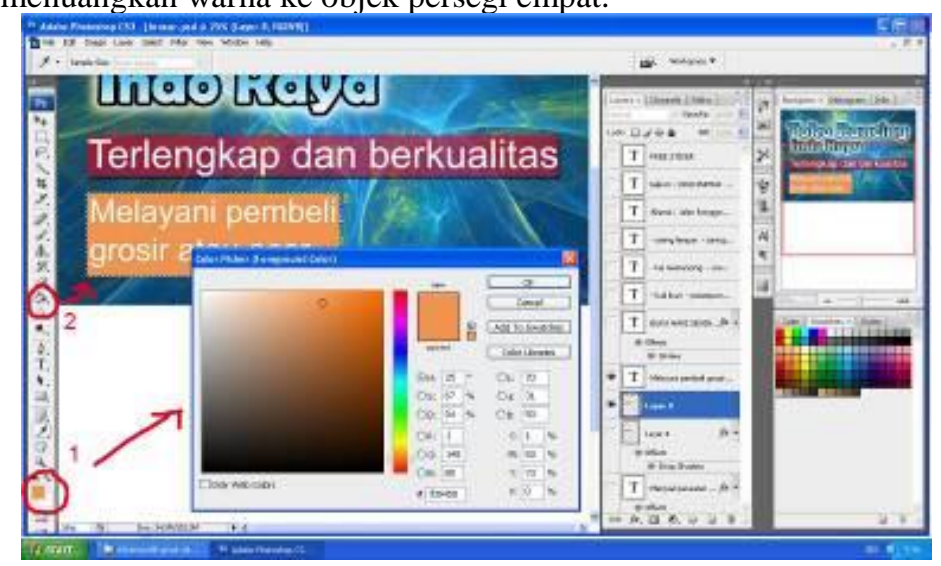

Gambar 4. 39 Memberi warna pada objek persegi empat.

(13). Memberi efek Drop Shadow pada objek background persegi empat dengan cara klik Add a layer style lalu klik Drop Shadow dan atur setingan Drop Shadow Opacity 75\%, Angle 120 derajat, Distance 24px, Spread 18\%, Size 10px. 


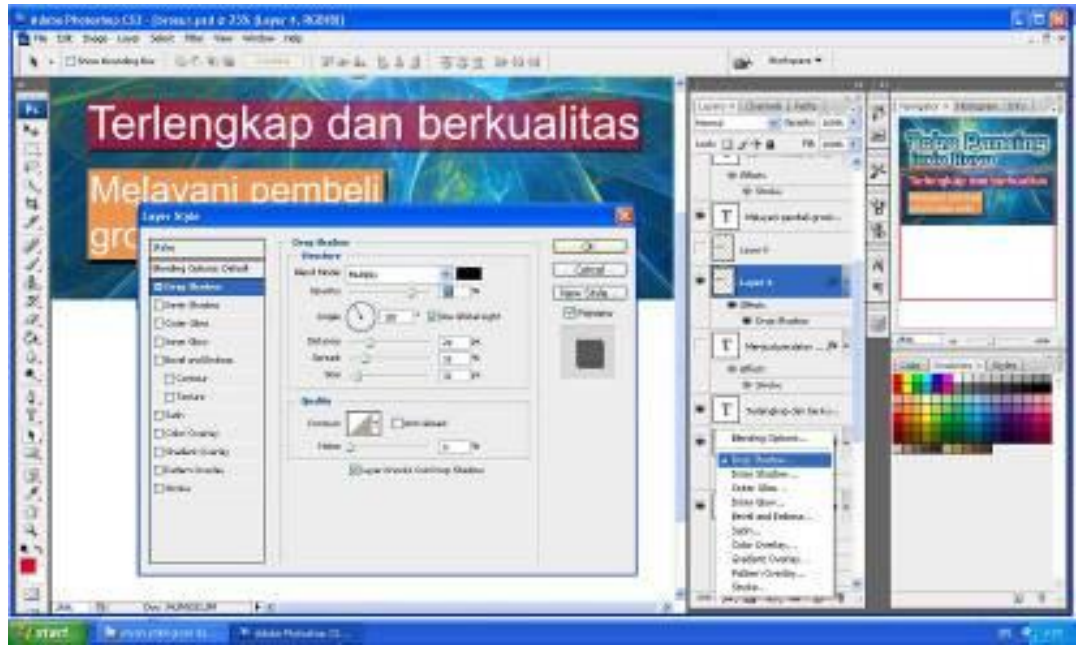

Gambar 4. 40 Langkah memberi efek Drop Shadow.

(14). Langkah selanjutnya menambahkan text "Free Stiker" dengan menggunakan text tipe Arial dengan cara klik Horizontal Type Tool lalu ketik text, setelah text diketik lalu putar text menggunakan Move Tool lalu putar hingga -17,7 derajat.

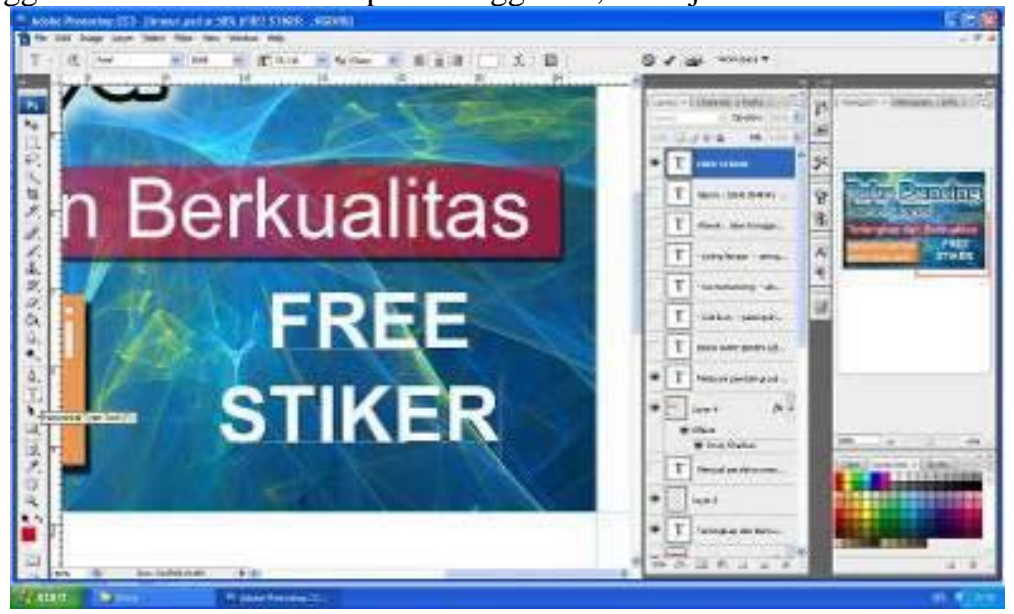

Gambar 4. 41 Mengetik text "Free Stiket".

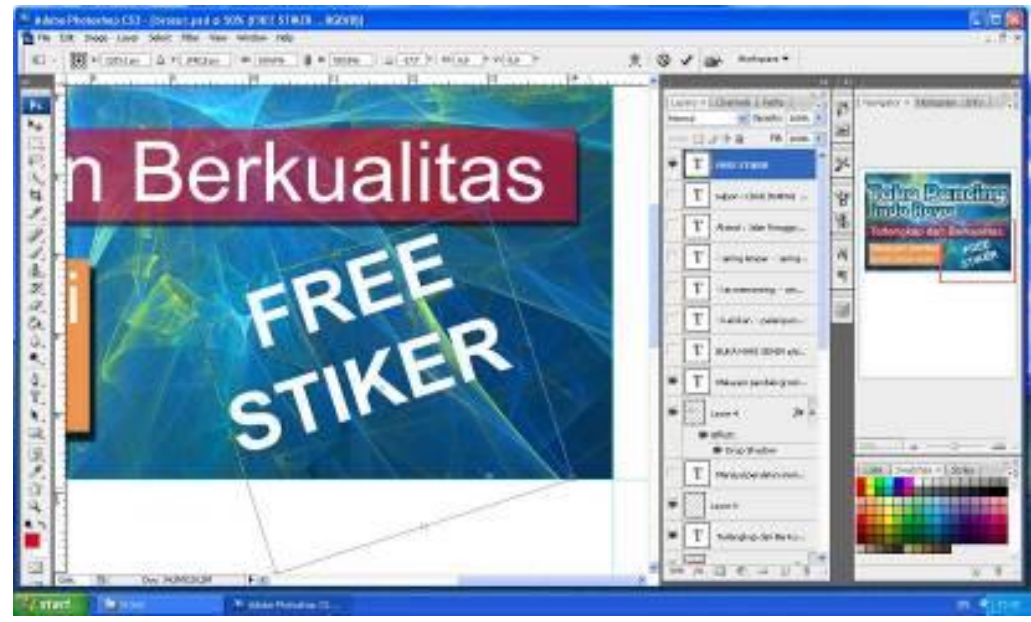

Gambar 4. 42 Langkah memutar text menggunakan Move Tool.

(15). Tahap selanjutnya masih mengetik text informasi tentang jadwal buka dan tutupnya Toko Pancing Indo Raya dan text informasi "menjual peralatan memancing dan aksesoris"dengan menggunakan Horizontal type tool lalu ketik text mengunakan tipe font Arial. 


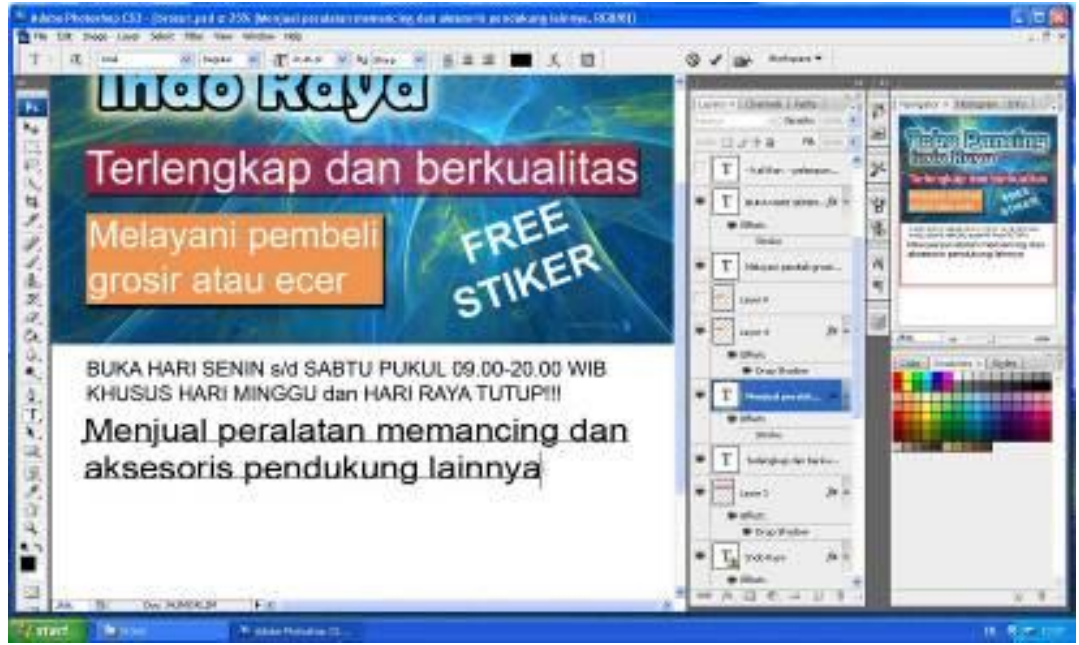

Gambar 4. 43 Mengetik text informasi.

(16). Berikutnya langkah membuat background ke dua sebelumnya masukan file gambar background ke layout dengan cara klik file - open lalu pilih gambar background yang akan di masukan setelah itu klik open.

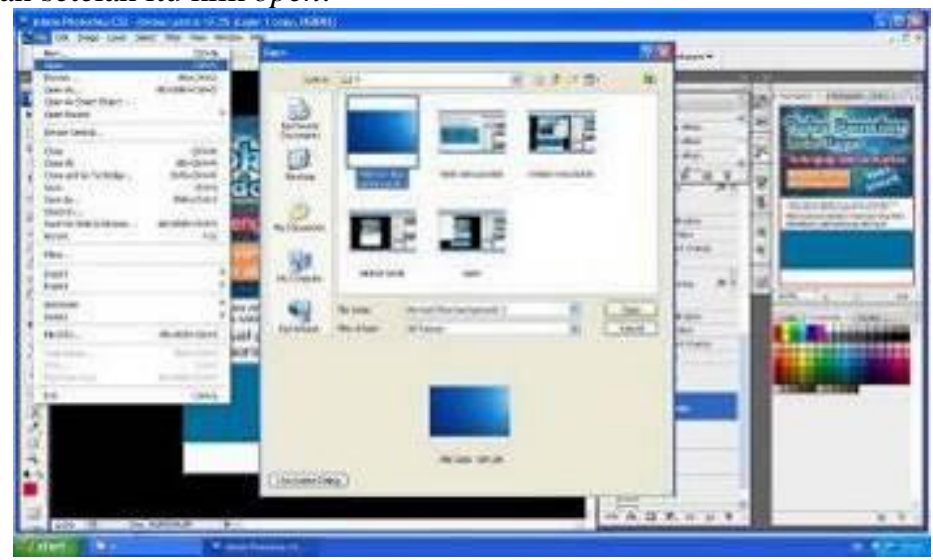

Gambar 4. 44 Open file background.

(17). Langkah selanjutnya buat persegi empat untuk membuat background dasar pada layout dengan cara klik Ractangular marquee tool lalu klik kiri tahan dan geser hingga membentuk seleksi persegi setelah itu berikan warna biru untuk background dasar dengan cara klik Set Foreground Color - klik Paint Bucket Tool.

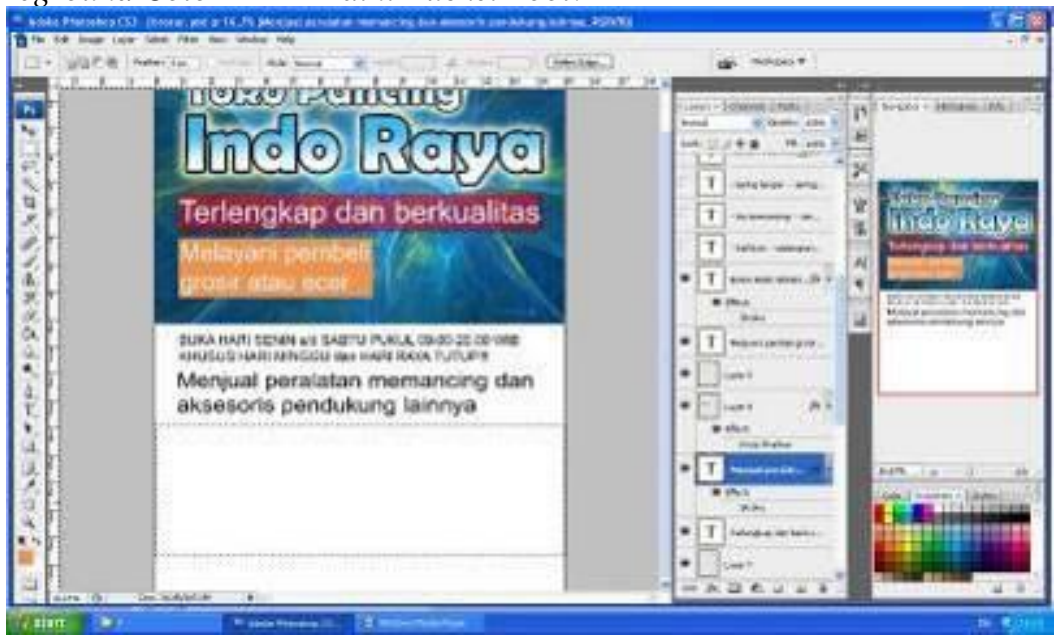

Gambar 4. 45 Membuat persegi empat untuk background dasar. 
61

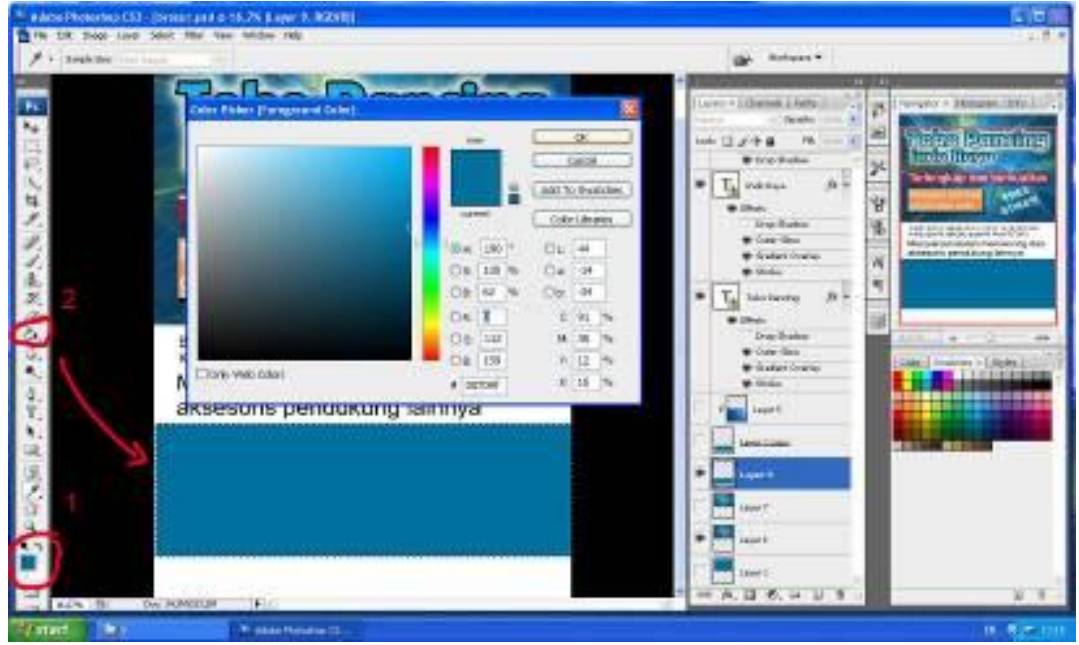

Gambar 4. 46 Memberi warna background dasar.

(18). Selanjutnya masukan gambar background ke dalam layout dengan cara drag gambar menggunakan Move Tool. Setelah gambar di masukan ke dalam layout langkah berikutnya menggabungkan gambar background dengan background dasar dengan cara klik gambar background lalu kursor arahkan ke layer background tekan Alt dan klik kiri pada mouse dengan bersamaan agar gambar background menyatu bersama background dasar.

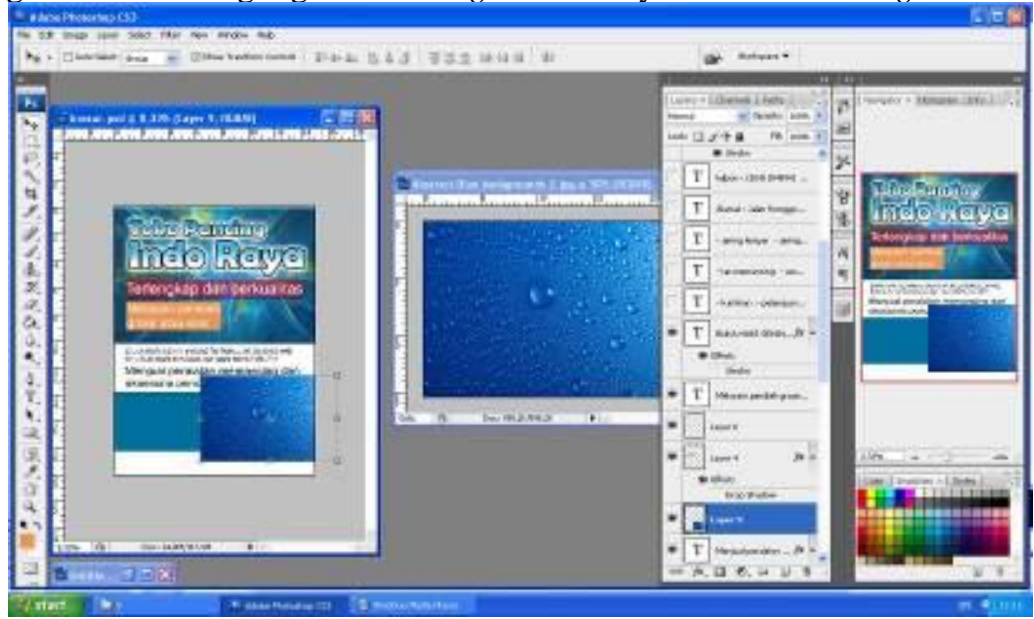

Gambar 4. 47 Memindahkan gambar background ke layout.

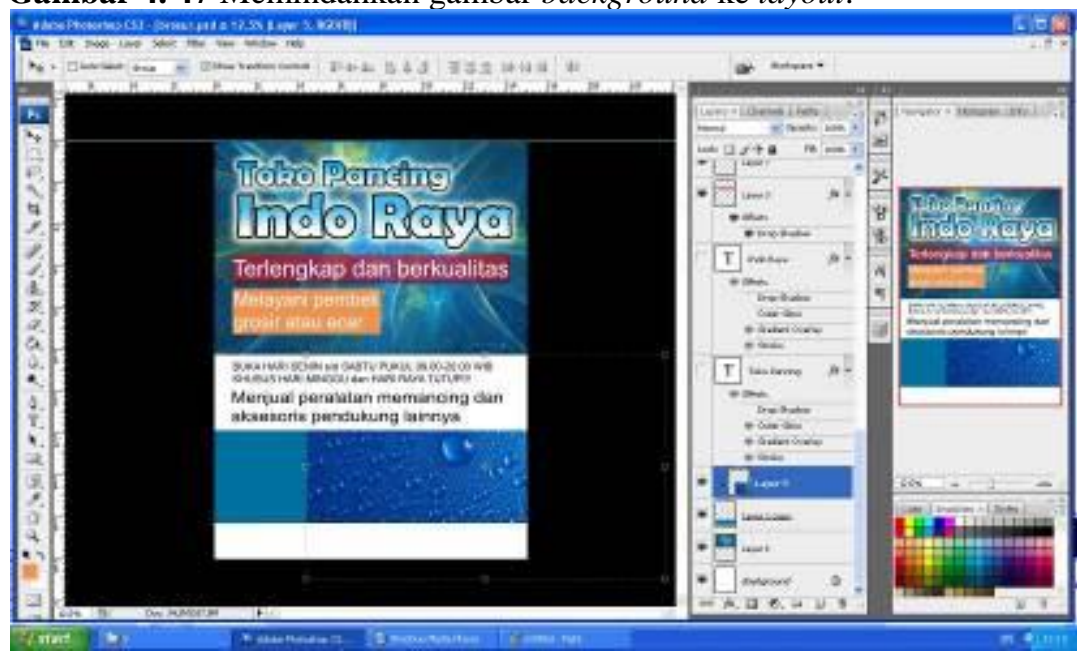

Gambar 4. 48 Menyatukan gambar background dengan background dasar. 
(19). Setelah gambar background jadi satu tahap berikutnya memberi efek Luminocity pada background untuk menyatukan warna gambar background dengan background dasar dengan cara klik layer gambar background lalu pilih set the bleanding mode for the layer yang ada di atas menu layer lalu pilih Luminocity agar warna background menyatu dan klik opacity $55 \%$.

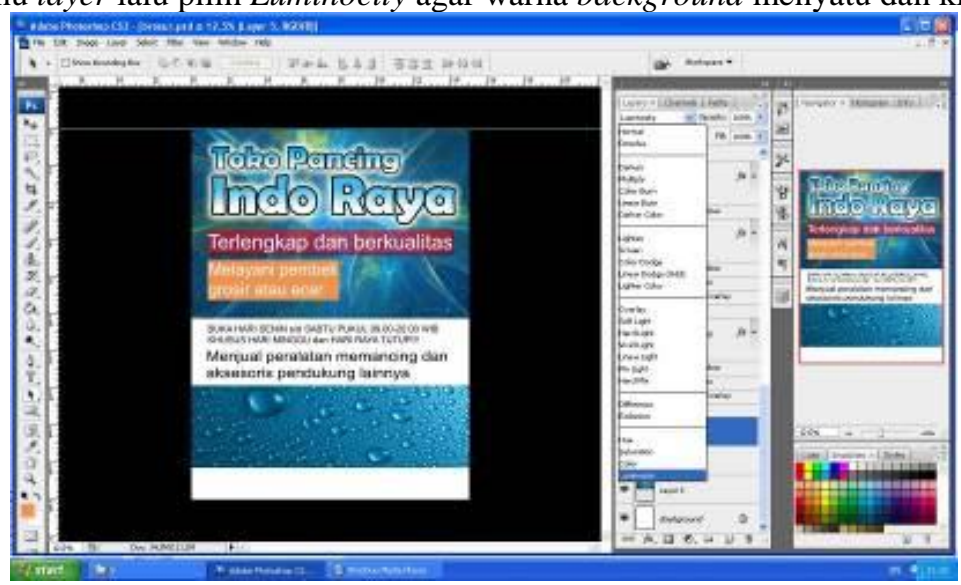

Gambar 4. 49 Langkah memberi efek Luminocity pada background.

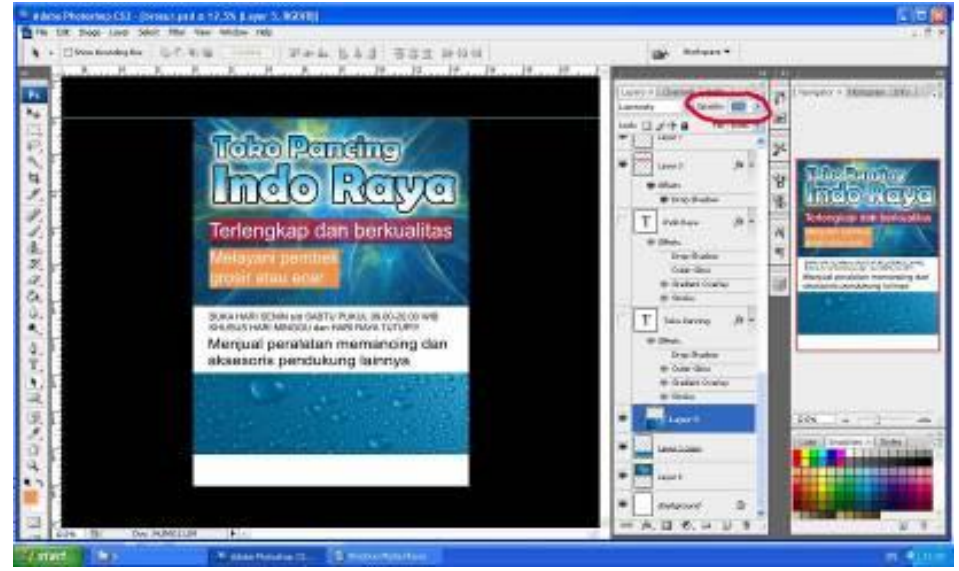

Gambar 4. 50 Menurunkan opacity background.

(20). Tahap berikutnya yaitu memberi text tentang isi menu produk yang dijual di Toko Pancing Indo Raya dan alamat serta nomer telepon toko, dengan cara klik Horizontal Type Tool lalu gunakan tipe text Arial ketik menu produk apa saja yang ada di toko di layout brosur.

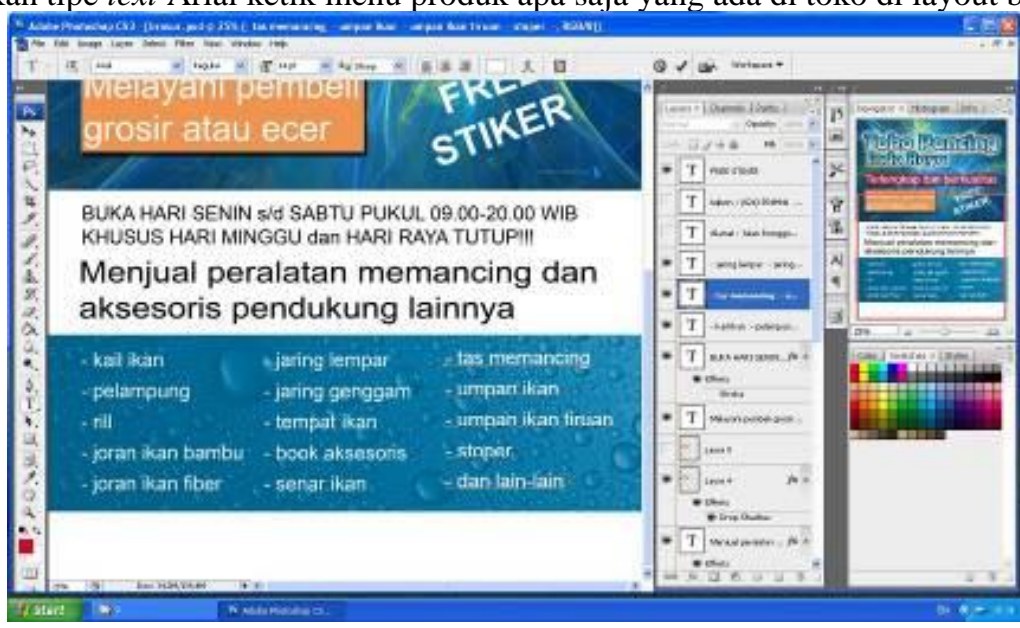

Gambar 4. 51 Text isi menu produk yang dijual. 
63

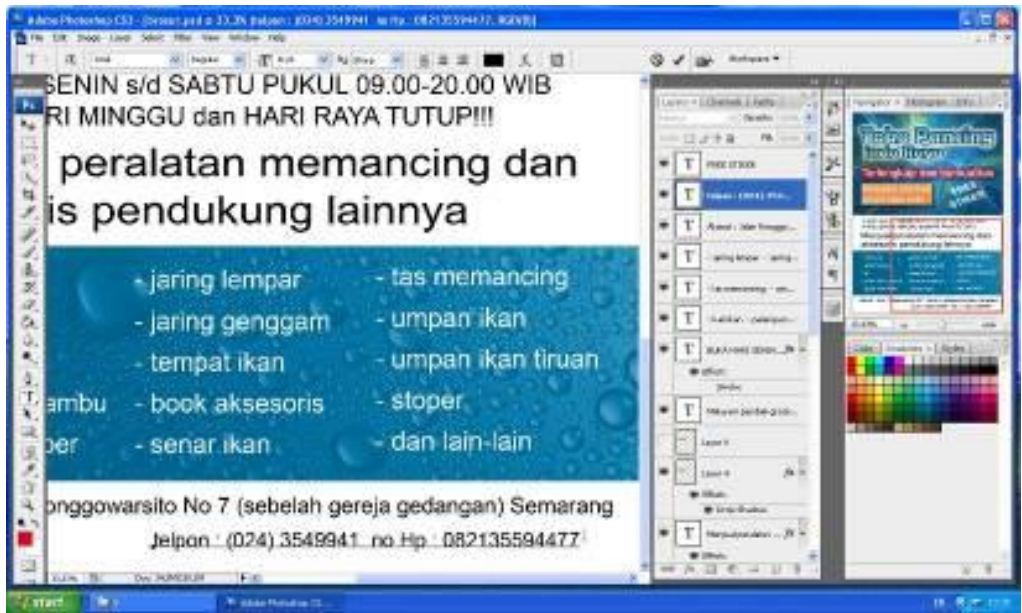

Gambar 4. 52 Text alamat serta nomer telepon Toko.

2. Pembuatan Desain Brosur Belakang.

a. Langkah pembuatan desain brosur bagian belakang :

(1). Klik file - new ( Ctrl $+N$ ) lalu atur ukuran width $15 \mathrm{~cm}$ dan height $20 \mathrm{~cm}$ dengan resolusi 200 pixel/inch.

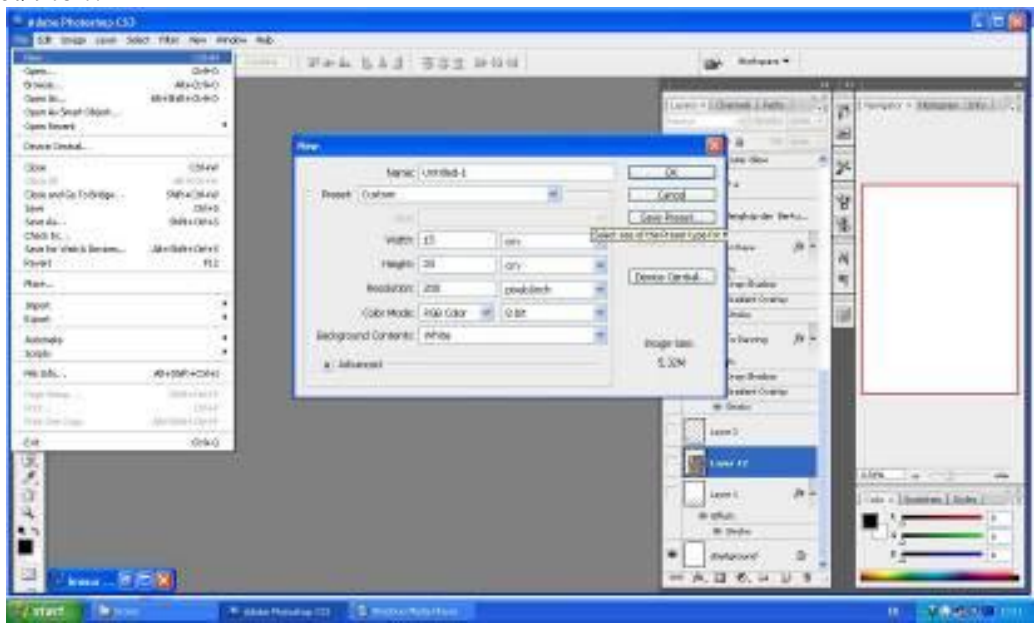

Gambar 4. 53 Langkah membuat new layout.

(2). Setelah new layout langkah berikutnya yaitu memasukan file gambar untuk background bagian atas dengan cara klik file - open $(\mathrm{Ctrl}+\mathrm{O}$ ) lalu pilih gambar background yang akan di pakai lalu klik open.

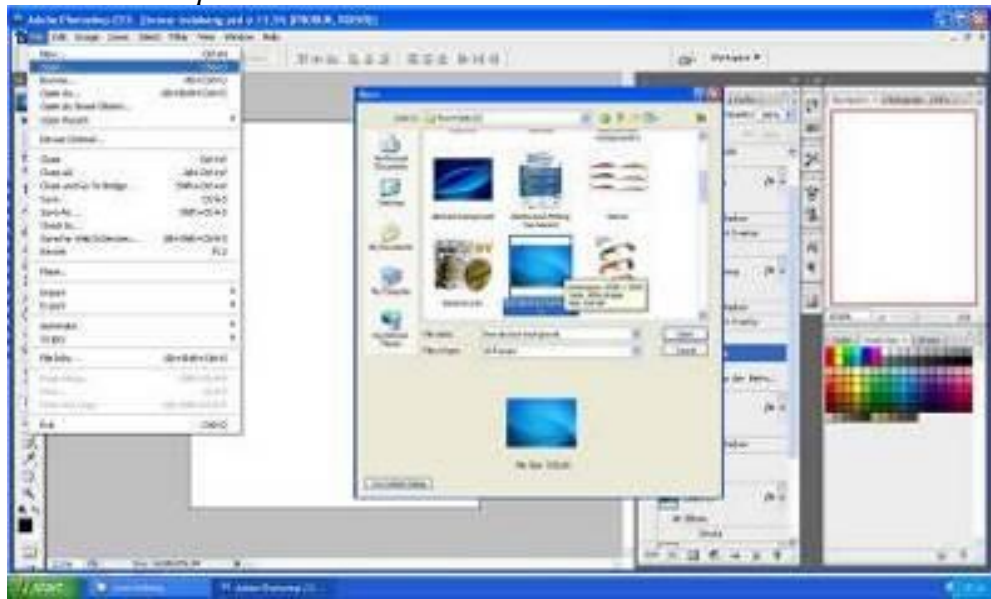

Gambar 4. 54 Langkah membuka file gambar background. 
(3). Langkah selanjutnya memindahkan gambar background ke dalam layout yaitu menggunakan Move Tool lalu tekan tahan dan geser gambar ke layout agar gambar masuk ke dalam layout.

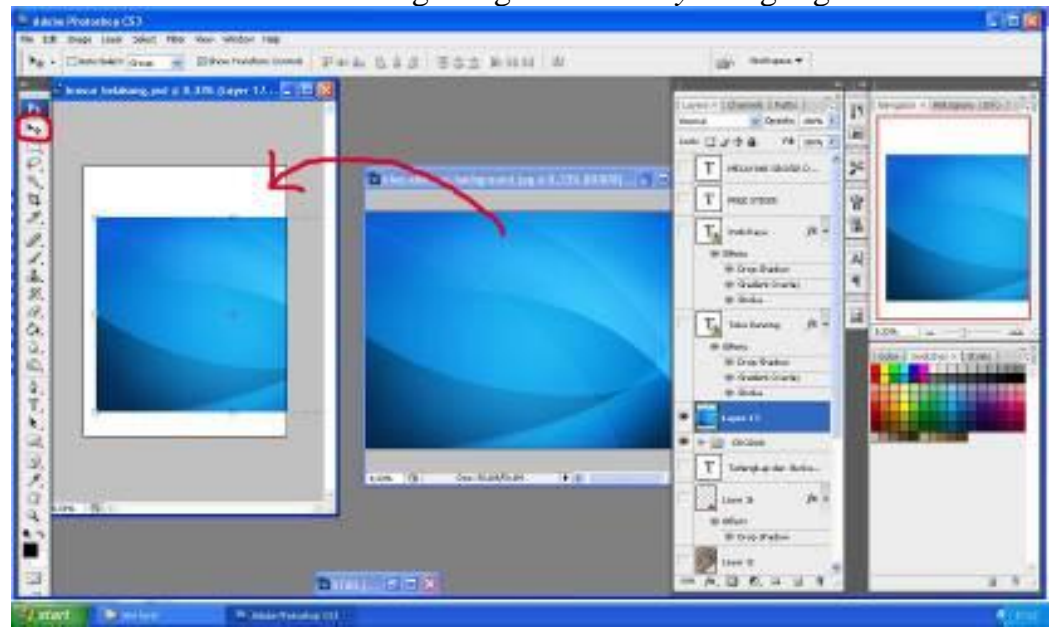

Gambar 4. 55 Langkah memindahkan background.

(4). Selanjutnya yaitu memberi efek stroke pada background dengan cara klik Add a layer style lalu pilih Stroke dan atur size 50px lalu pilih warna kuning lalu klik $O K$.

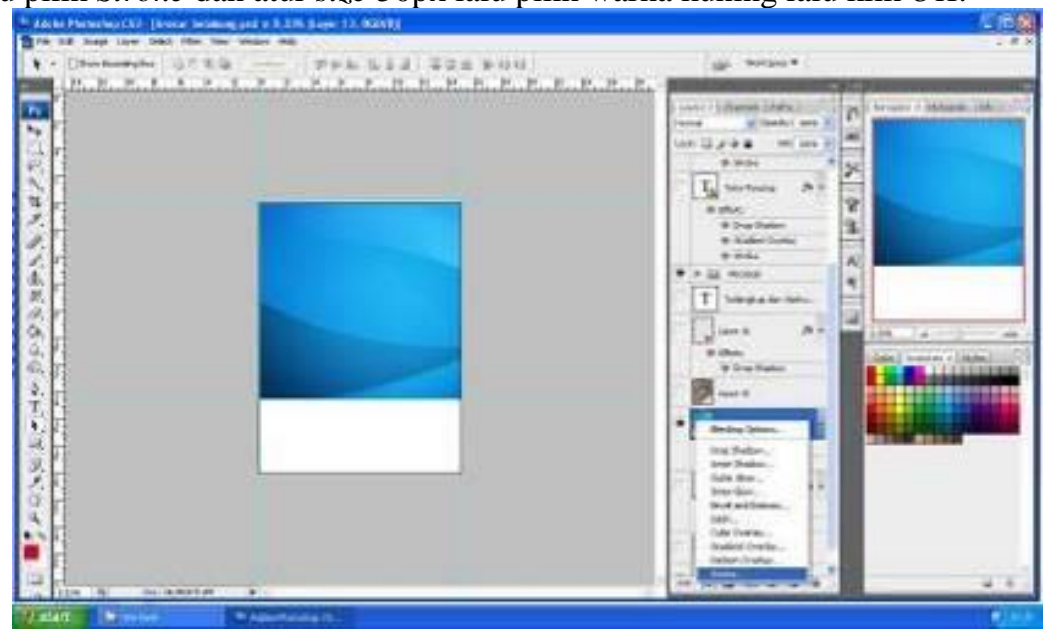

Gambar 4. 56 Langkah memberi efek stroke.

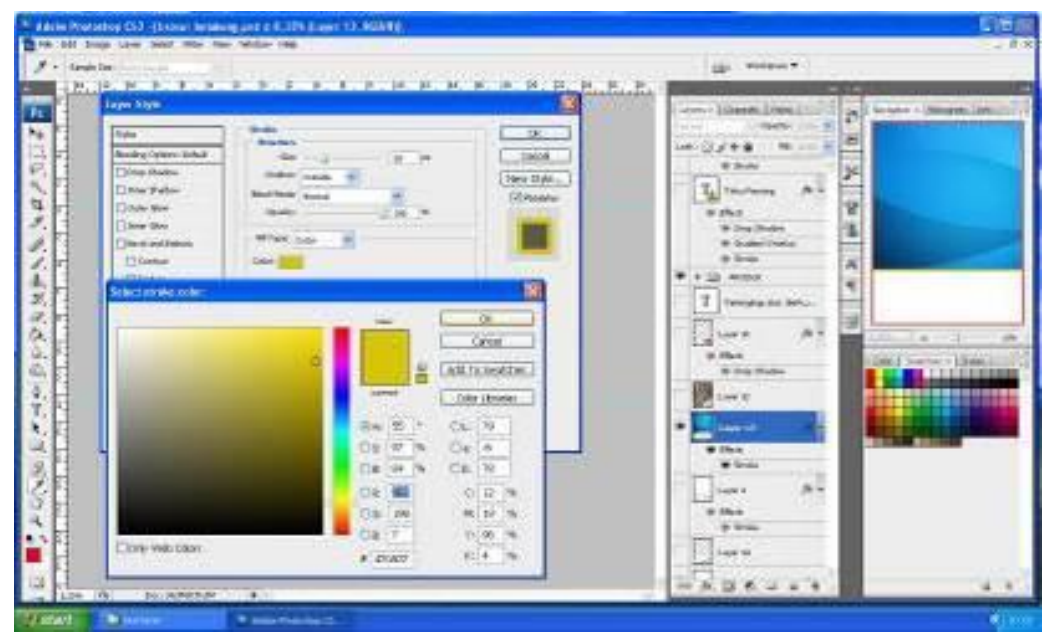

Gambar 4. 57 Langkah mengtur stroke. 
(5). Di tahap selanjutnya yaitu memberi gambar produk yang di jual di Toko Pancing Indo Raya kedalam brosur langkah awalnya yaitu klik file - open lalu pilih foto produk yang akan di gunakan lalu klik open atau bias juga dengan mendrag gambar dengan mouse ke dalam layout menggunakan Move Tool.

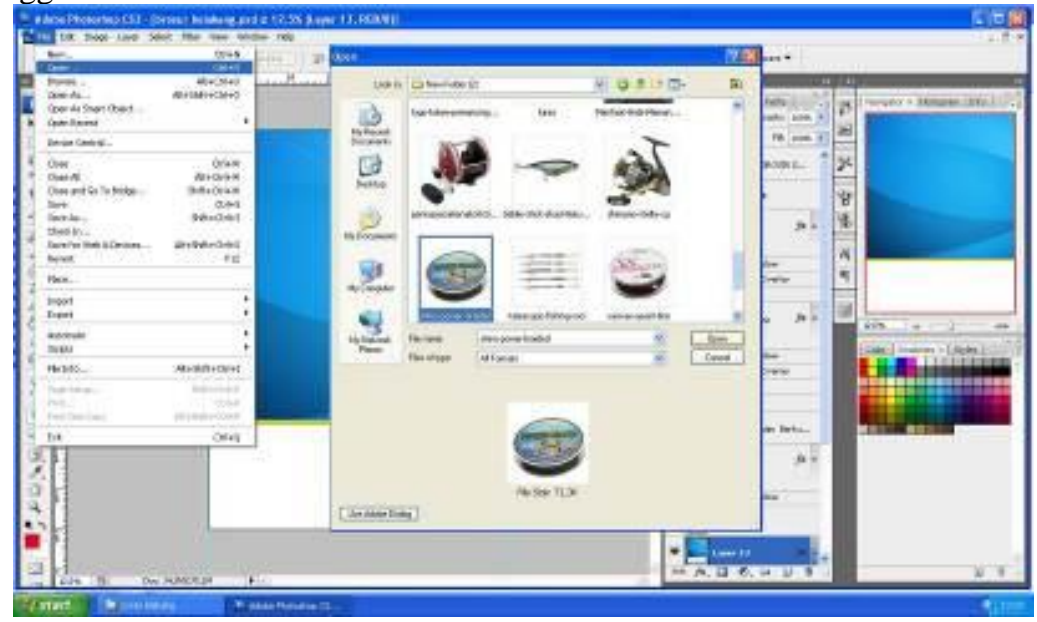

Gambar 4. 58 Langkah membuka file foto produk.

(6). Langkah selanjutnya memotong foro produk agar terpisah dengan background foto dengan cara klik Magic Wand Tool lalu klik ke background berwarna putih yang ada di foto produk lalu background akan terseleksi setelah itu tekan tombol delete pada keyboard jika sudah background warna putih akan hilang.

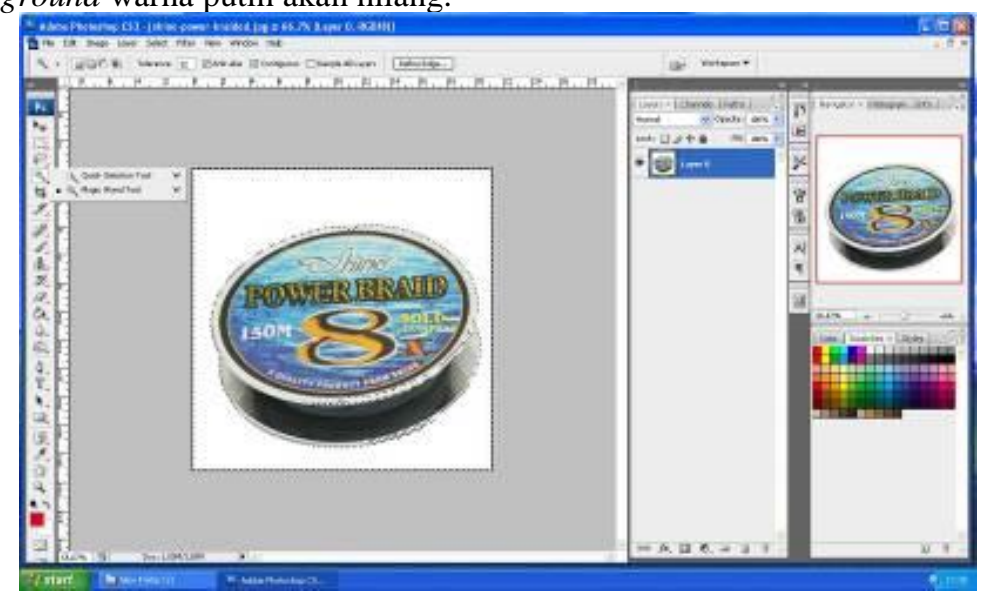

Gambar 4. 59 Menghilangkan background dengan Magic Wand Tool.

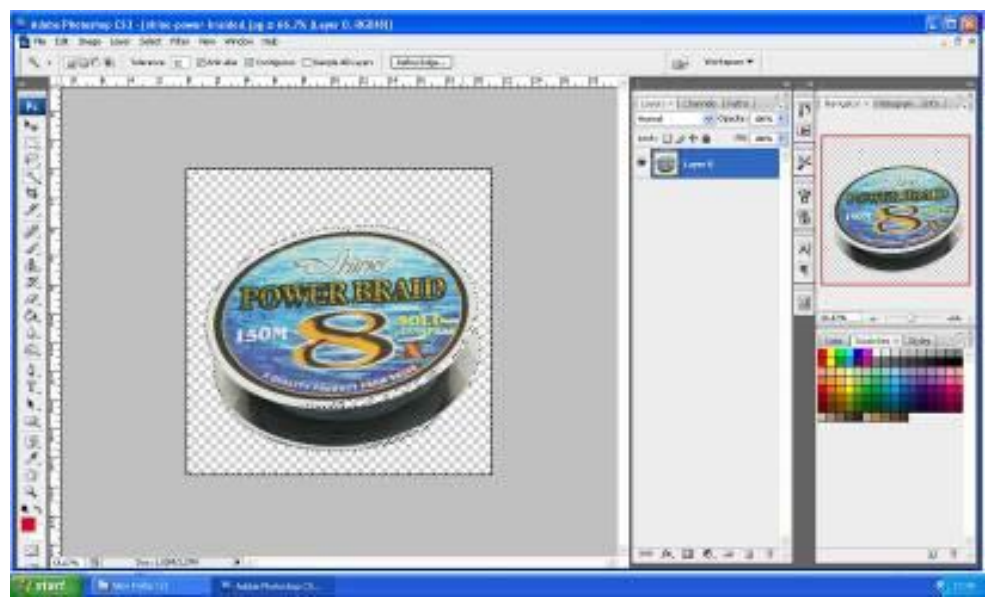

Gambar 4. 60 Hasil background yang sudah hilang. 
(7). Tahap selanjutnya yaitu memindahkan objek foto produk ke dalam layout dengan cara menggunakan move tool.

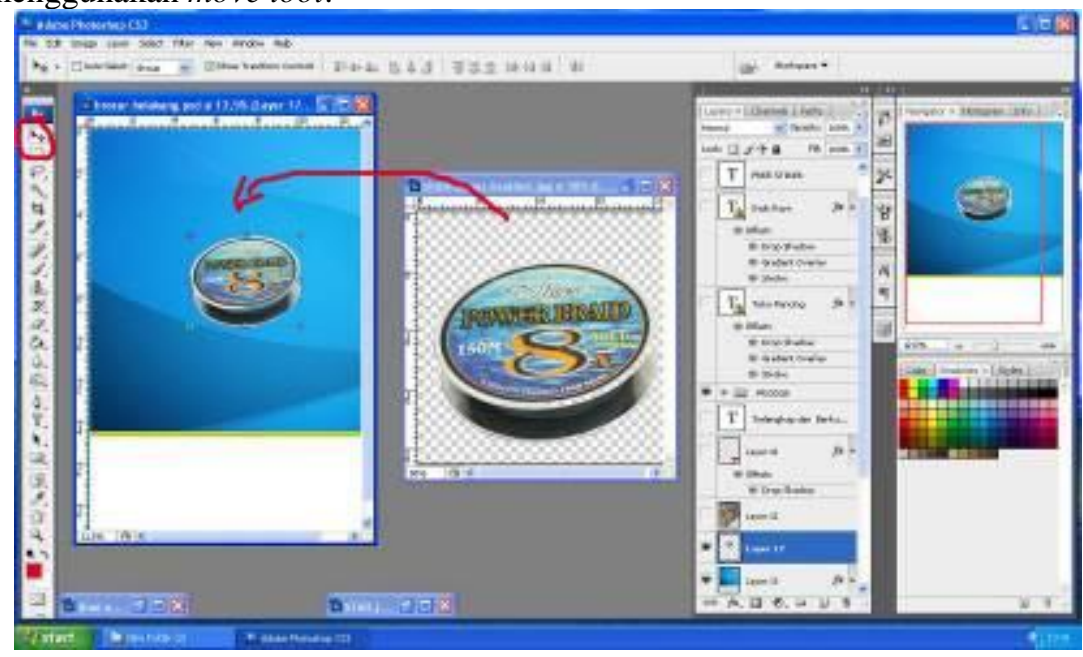

Gambar 4. 61 Memindahkan foto produk menggunakan Move Tool.

(8). Setelah semua foto produk di pindahkan jadi satu ke layer langkah selanjutnya yaitu memberi efek Outner Glow dengan cara klik Add a layer style lalu pilih Outner Glow setelah itu atur Opacity $75 \%$, Size $100 \mathrm{px}$, range $50 \%$.

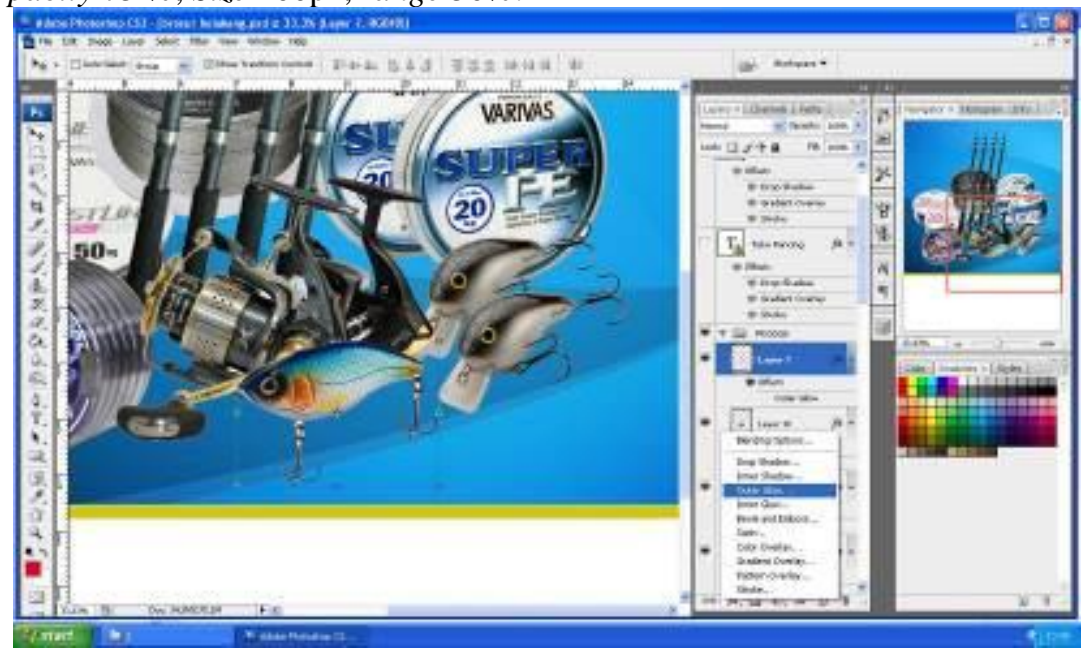

Gambar 4. 62 Langkah memberi efek Outner Glow pada foto produk.

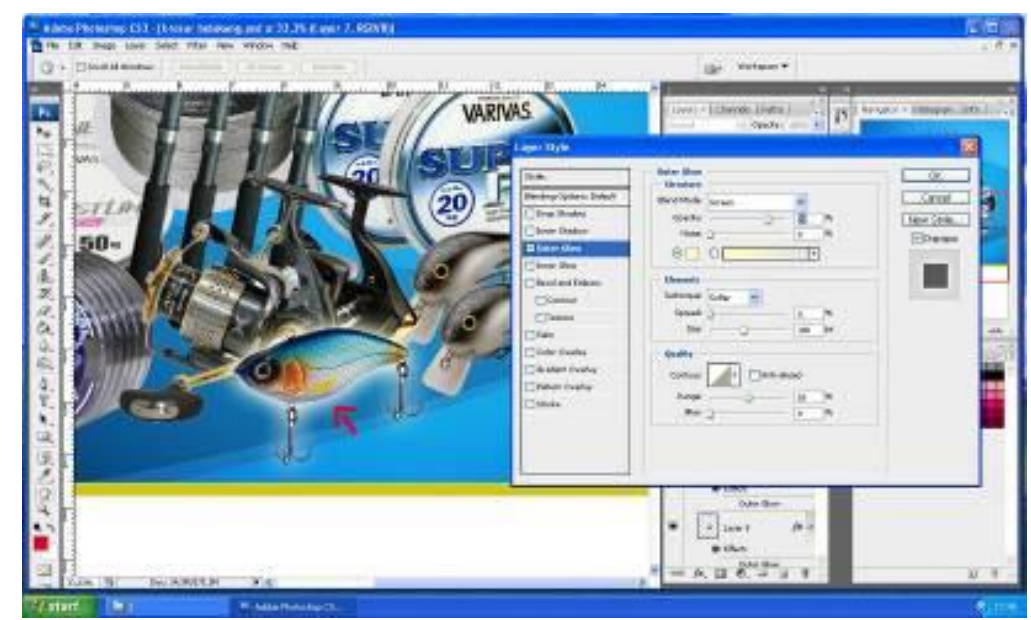

Gambar 4. 63 Langkah mengatur efek Outner Glow. 
67

(9). Untuk tahap bagian bawah brosur akan diisi dengan denah lokasi, langkah awal pembuatan denah lokasi menggunakan software Corel Draw X4. Langkah pertama buka Corel Draw X4, setelah itu membuat bentuk dua lingkaran dengan klik Ellipse Tool dan tekan tombol Ctrl agar objek berbentuk lingkaran sempurna lalu klik + untuk menduplikat objek lingkaran, agar menjadi dua lingkaran untuk memperkecil lingkaran tekan tombol shift lalu drag objek agar objek tetap berada pada posisi tengah.

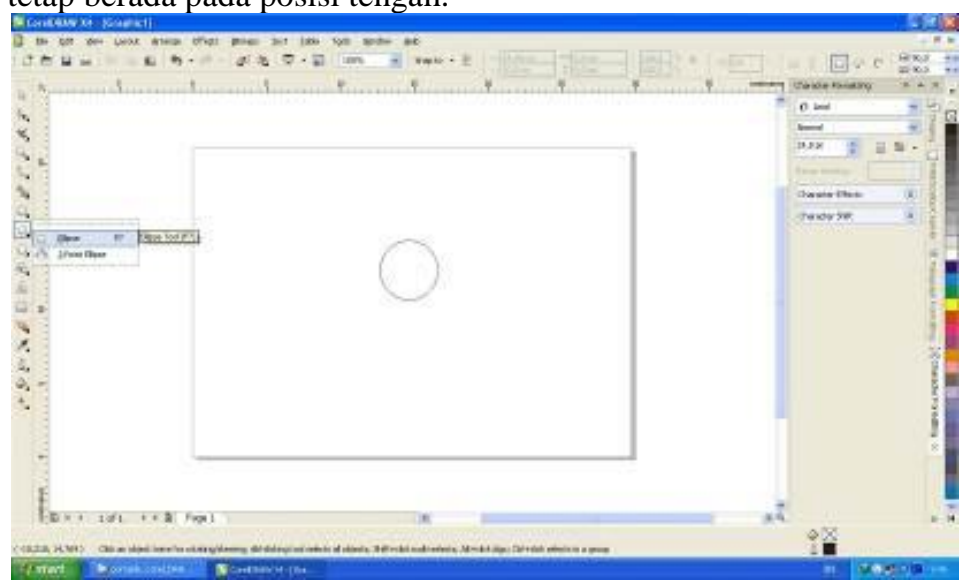

Gambar 4. 64 Langkah membuat lingkaran.

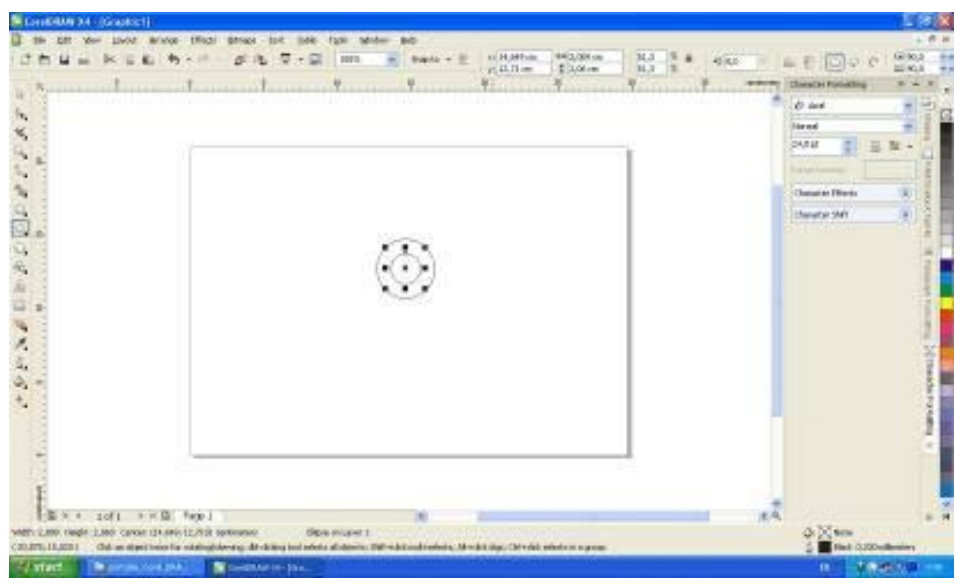

Gambar 4. 65 Langkah menduplikat lingkaran.

(10). Setelah membuat objek lingkaran, berikutnya membuat objek persegi empat untuk bagian jalan dengan menggunakan Rectangle Tool (F6), lalu gabungkan objek persegi empat dengan objek lingkaran lalu seleksi kedua objek tersebut tekan shift dengan ditahan lalu klik kedua objek tersebut, setelah objek terseleksi klik Weld yang berfungsi untuk menyatukan kedua objek tersebut.

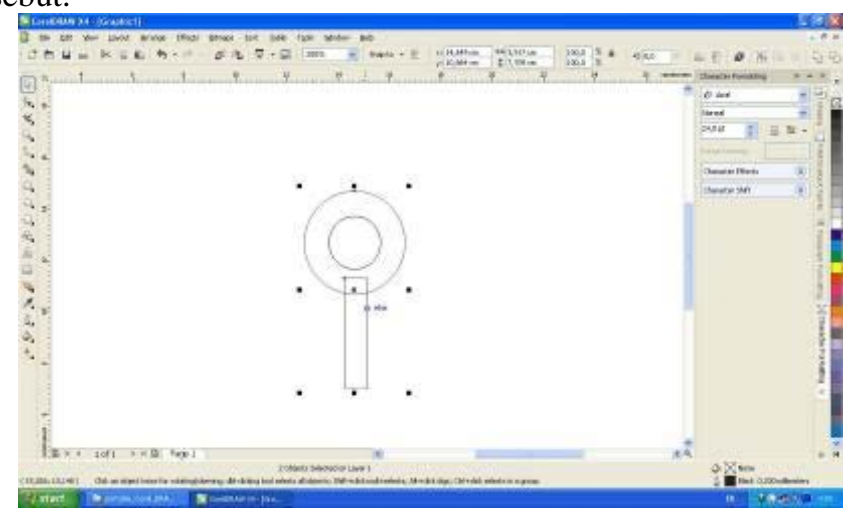

Gambar 4. 66 Seleksi kedua objek. 


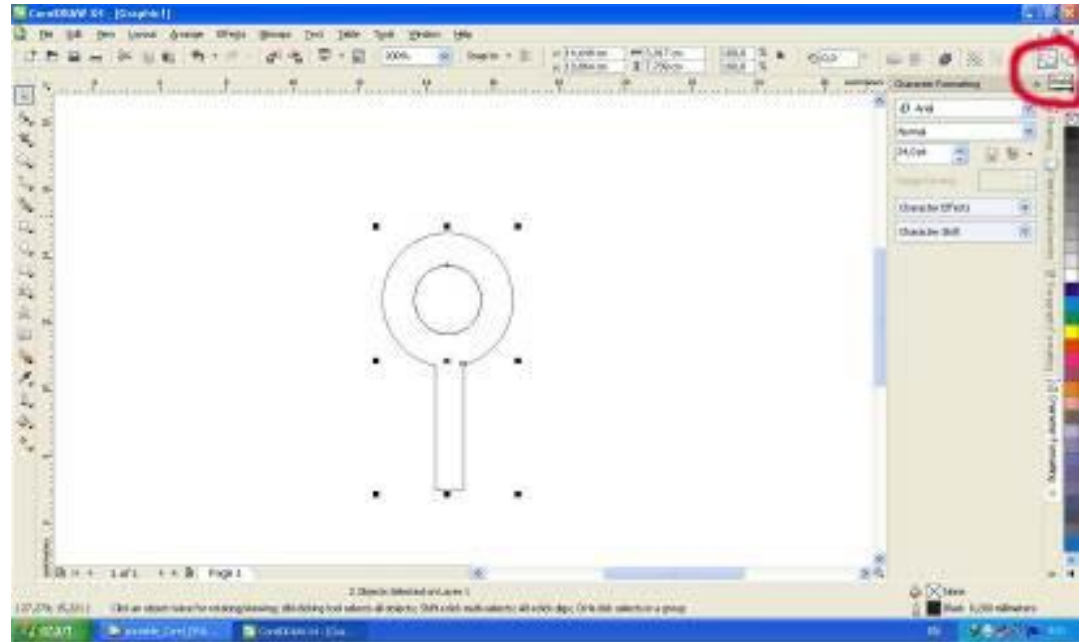

Gambar 4. 67 Menyatukan kedua objek menggunakan Weld.

(11). Setelah semua persegi disatukan menggunakan Weld langkah selanjutnya yaitu memberi efek Outline pada objek yang berfungsi memberikan ketebalan garis pada objek dan untuk mempertegas objek itu sendiri, ketebalan objek yang digunakan yaitu $2 \mathrm{pt}$.

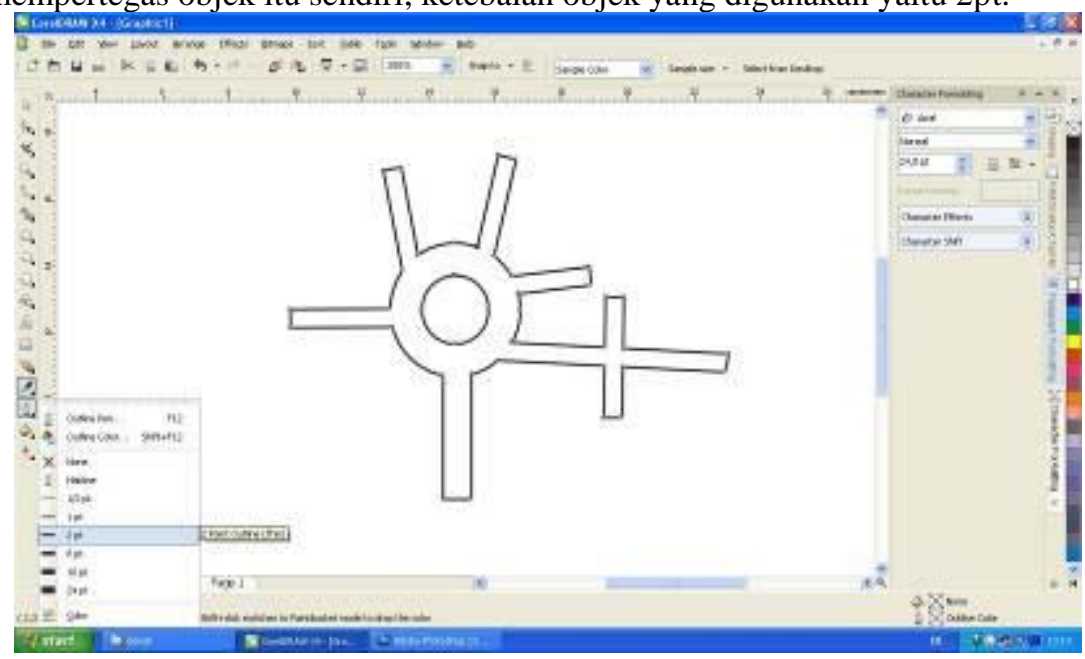

\section{Gambar 4. 68 Memberi efek Outline.}

(12). Langkah selanjutnya beralih ke software Photoshop Cs3 untuk memasukan gambar denah ke dalam desain brosur, klik file - open lalu pilih gambar denah yang akan dimasuka ke dalam brosur lalu klik open.

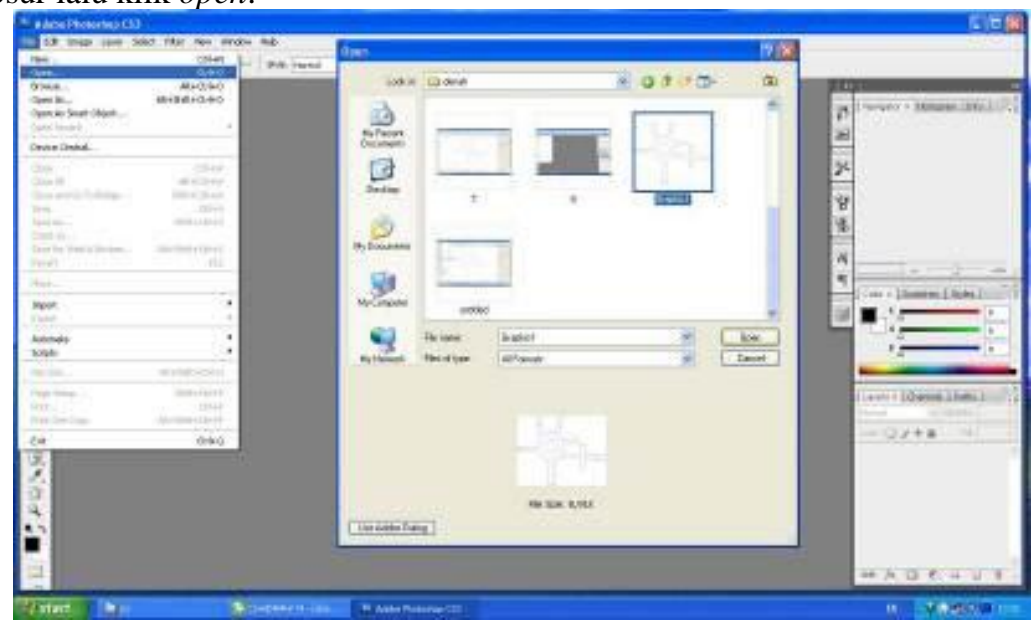

Gambar 4. 69 Membuka file denah. 
69

(13). Setelah gambar denah di buka berikutnya yaitu memindahkan gambar denah ke brosur dengan cara klik Move Tool lalu drag gambar denah menggunakan Move Tool ke dalam brosur.

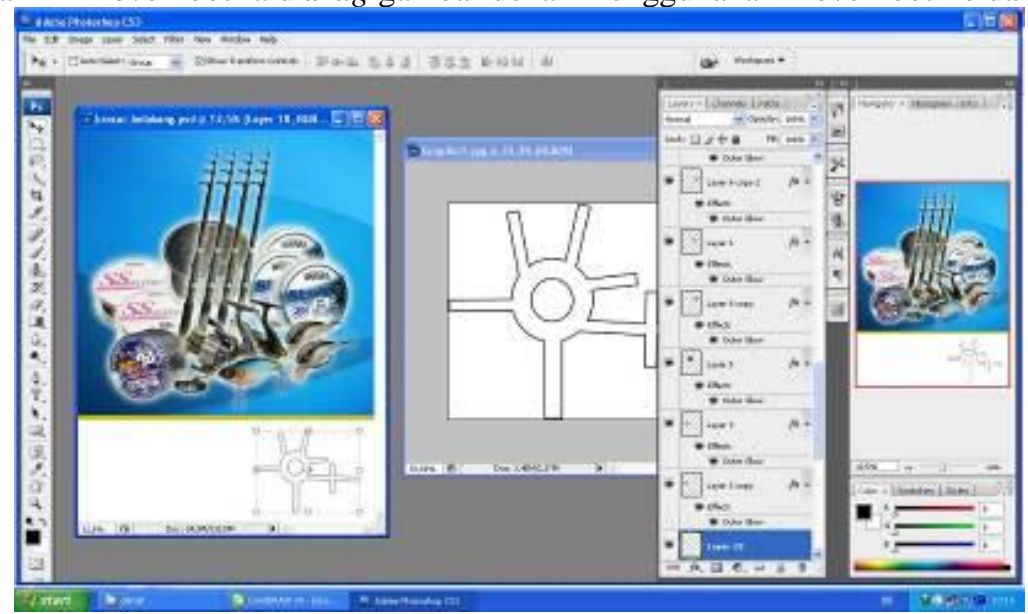

Gambar 4. 70 Memindahkan gambar denah ke bosur.

(14). Langkah terakhir yaitu memberi text nama jalan dan lokasi denah pada brosur dengan menggunakan Horizontal type tool.

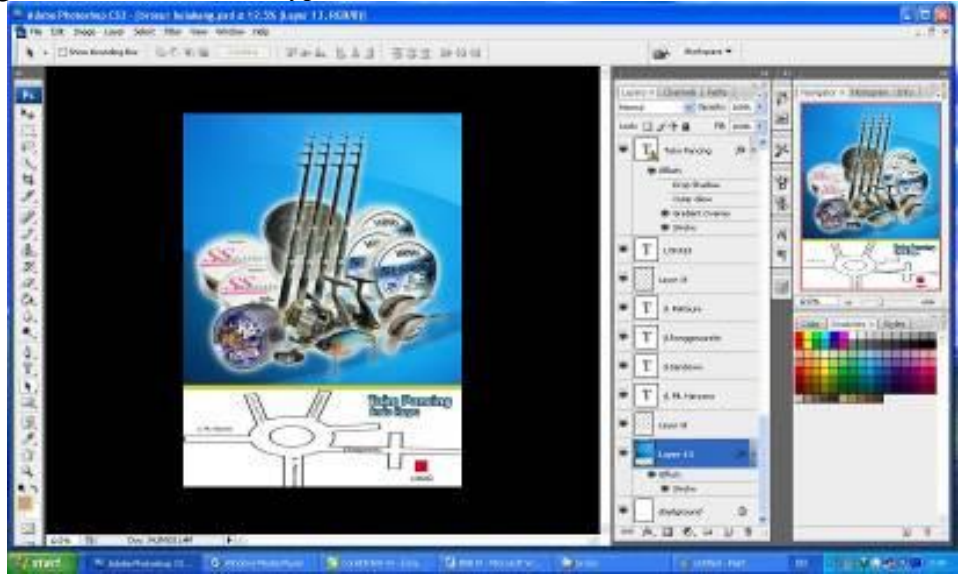

Gambar 4. 71 Menambahkan text nama jalan pada denah.

3. Pembuatan Desain $X-B e n n e r$.

a. Langkah pembuatan desain X-Benner :

(1). Langkah pertama membuat layout baru dengan klik file - new lalu atur ukuran layout dengan ukuran width $60 x$ height 160 resolusi 72 pixel/inch.

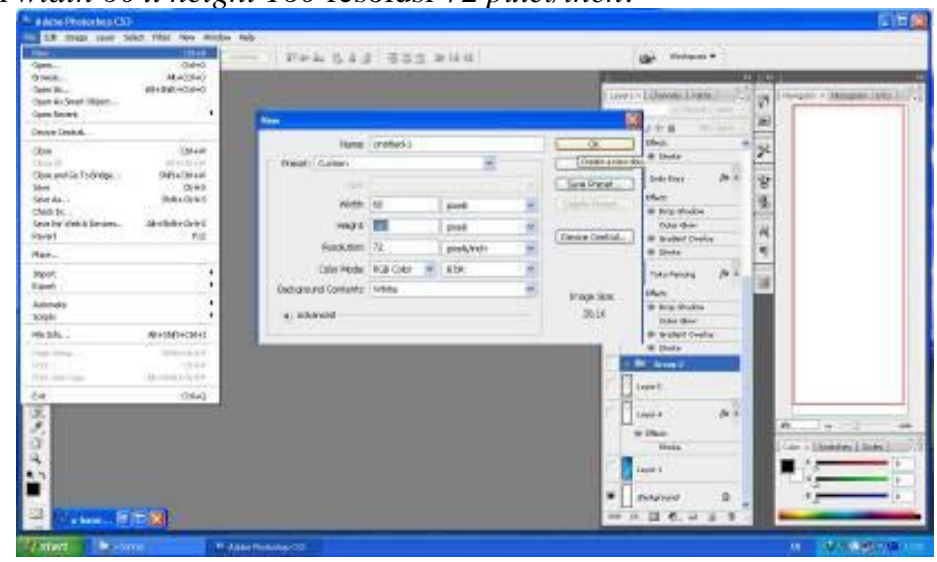

Gambar 4. 72 Langkah membuat new layout. 
(2). Lagkah selanjutnya mengambil gambar background dengan cara klik file - open lalu pilih gambar yang akan di gunakan.

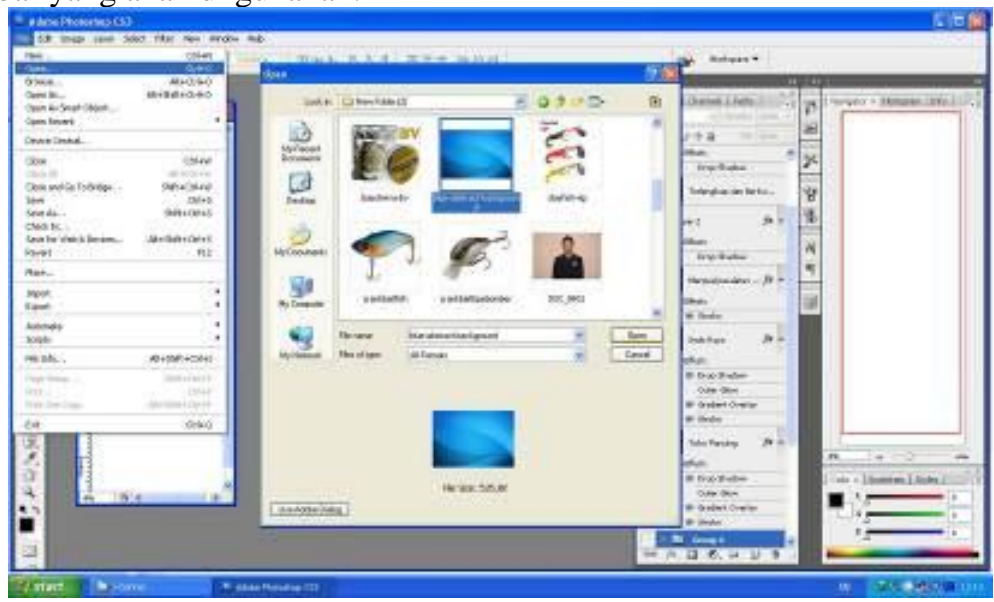

Gambar 4. 73 Langkah mengambil gambar background.

(3). Setelah mengambil gambar background lalu masukan background kedalam layout dengan menggunakan move tool lalu tarik gambar ke dalam layout.

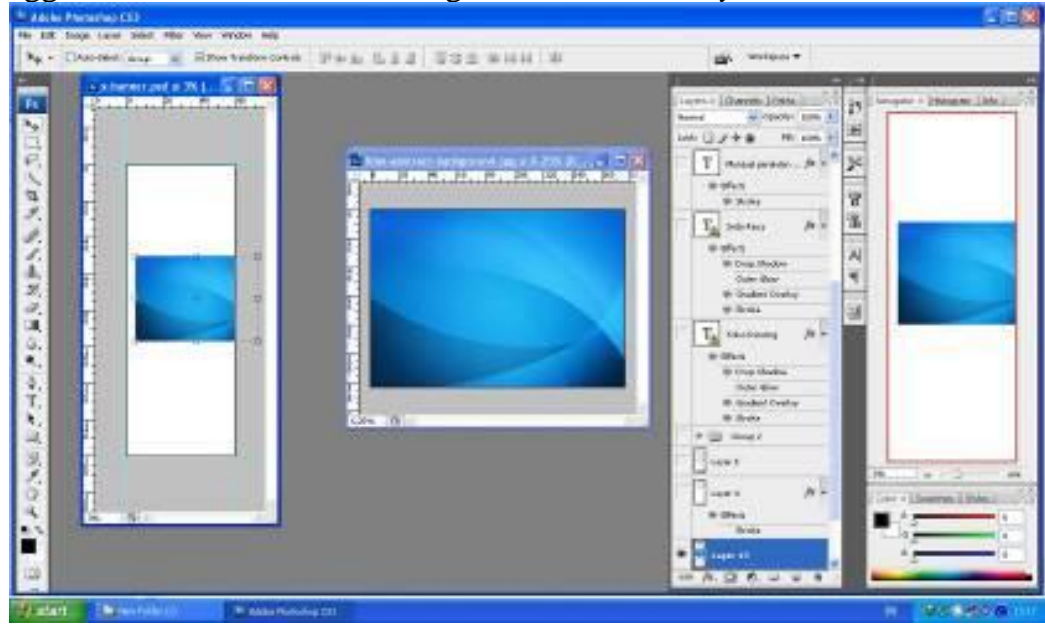

Gambar 4. 74 Memindahkan gambar background kedalam layout.

(4). Tahab berikutnya memberi nama toko, nama toko mengunakan yang sudah ada sebelumnya hanya memindahkan saja dengan menggunakan move tool.

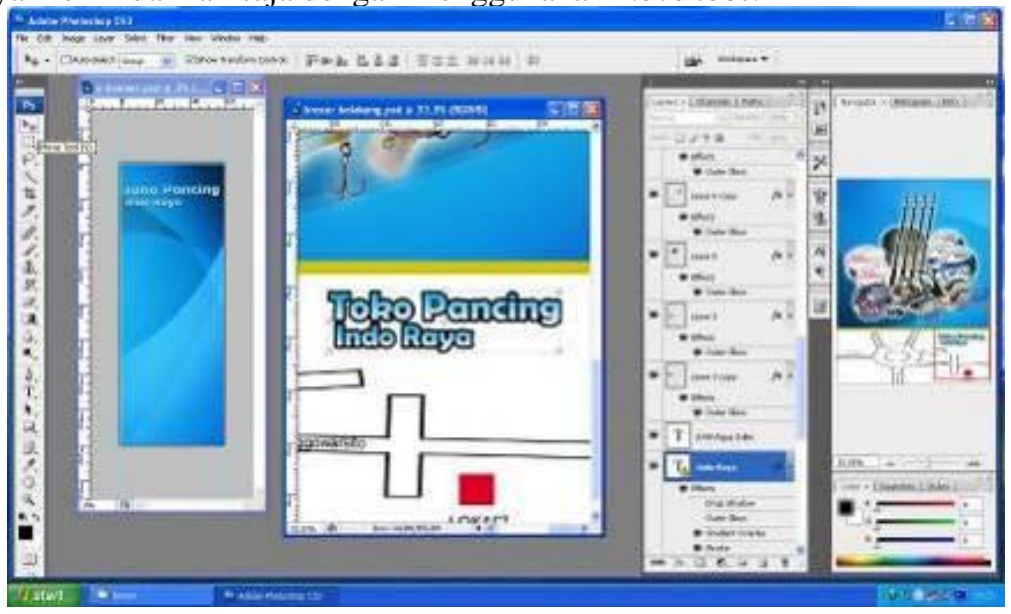

gambar 4. 75 Memasukan nama toko yang sudah ada. 
71

(5). Langkah berikutnya membuat line atau garis berbentuk persegi yang akan digunakan sebagai background dasar text yaitu klik create a new layer untuk membuat layer lalu klik Rectangular marquee lalu tarik memanjang ke dalam layout sampai terselaeksi setelah itu beri warna merah menggunakan paint bucket tool dan ketik text menggunakan Horizontal type tool.

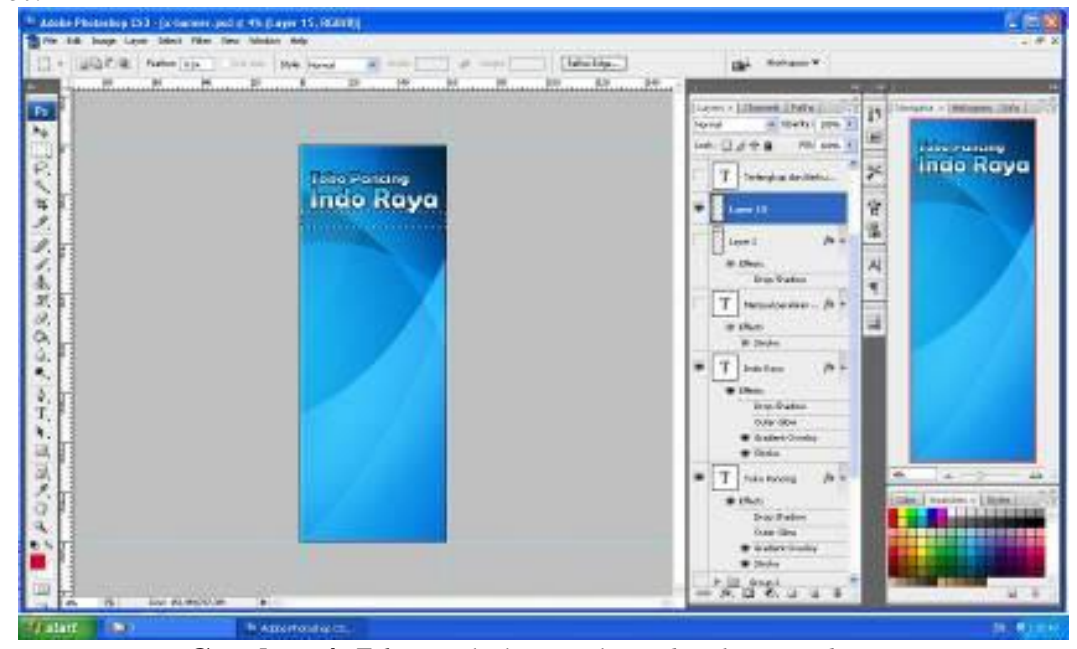

Gambar 4. 76 Langkah membuat background text.

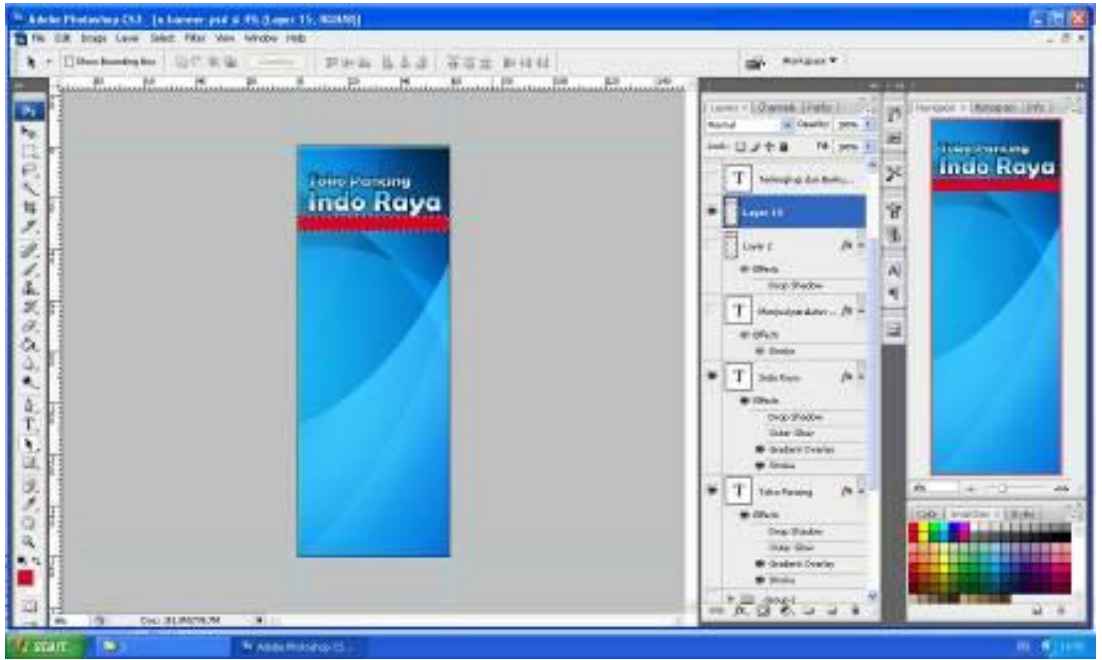

Gambar 4. 77 Memberi warna menggunakan paint bucket tool.

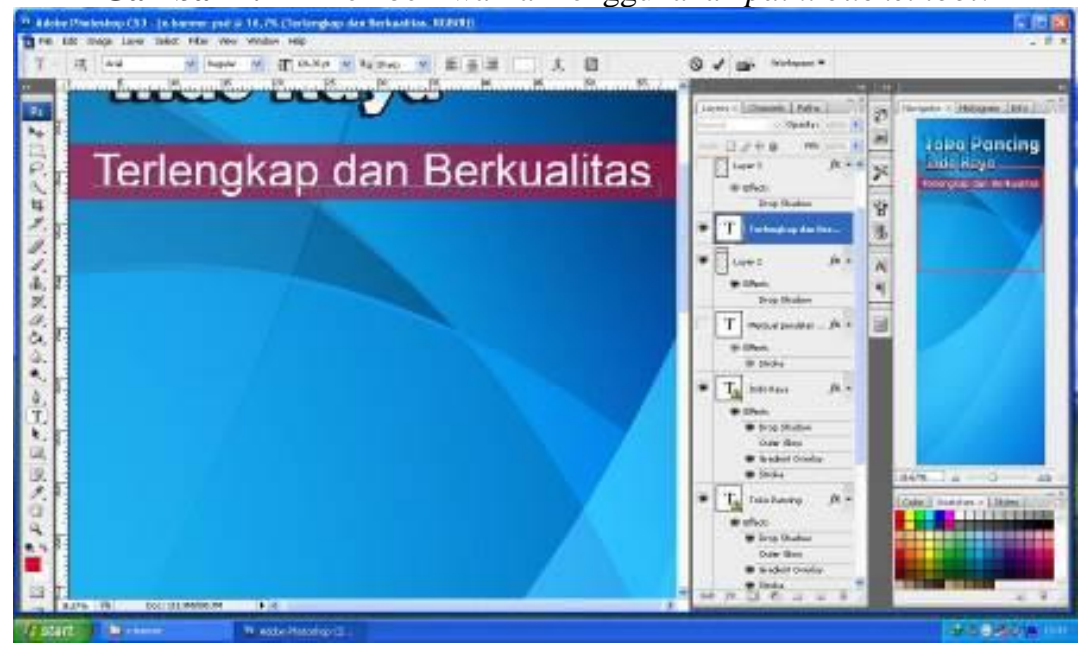

Gambar 4. 78 Memberi text "terlengkap dan berkualitas". 
(6). Setelah membuat background text selesai lalu berikutnya mengetik text "Menjual peralatan memancing dan akesoris" dengan menggunakan Horizontal type tool dan menggunakan efek stroke untuk mempertegas text dengan ukuran size $5 \mathrm{px}$ opacity $100 \%$.

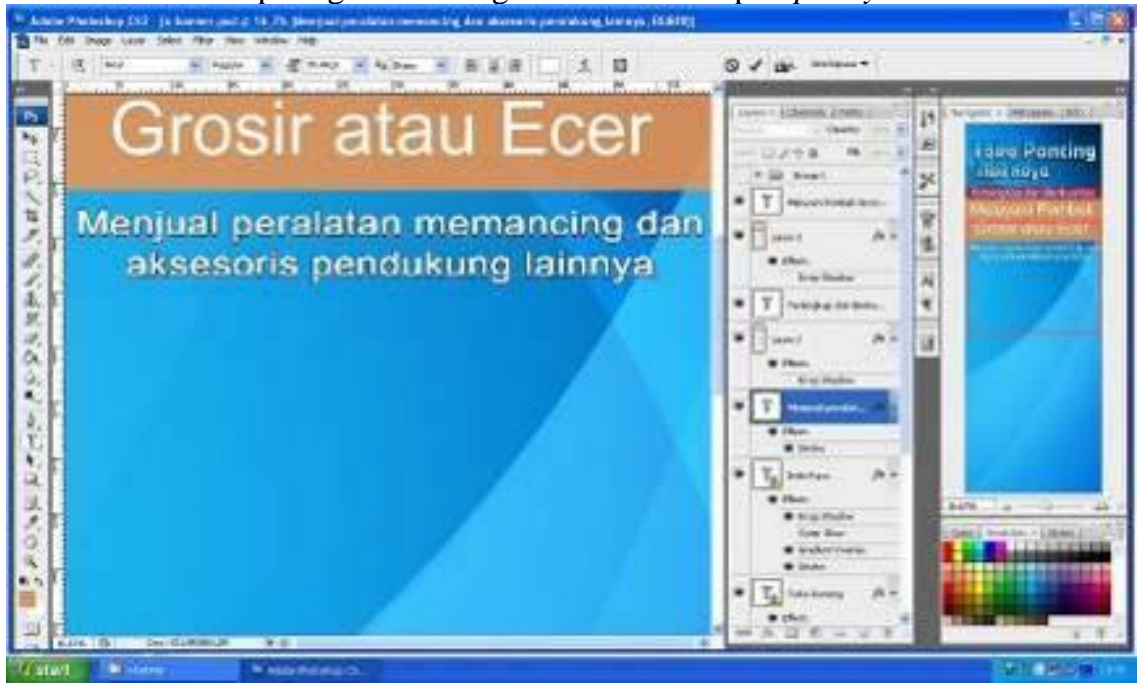

Gambar 4. 79 Text "Menjual peralatan memancing dan aksesoris".

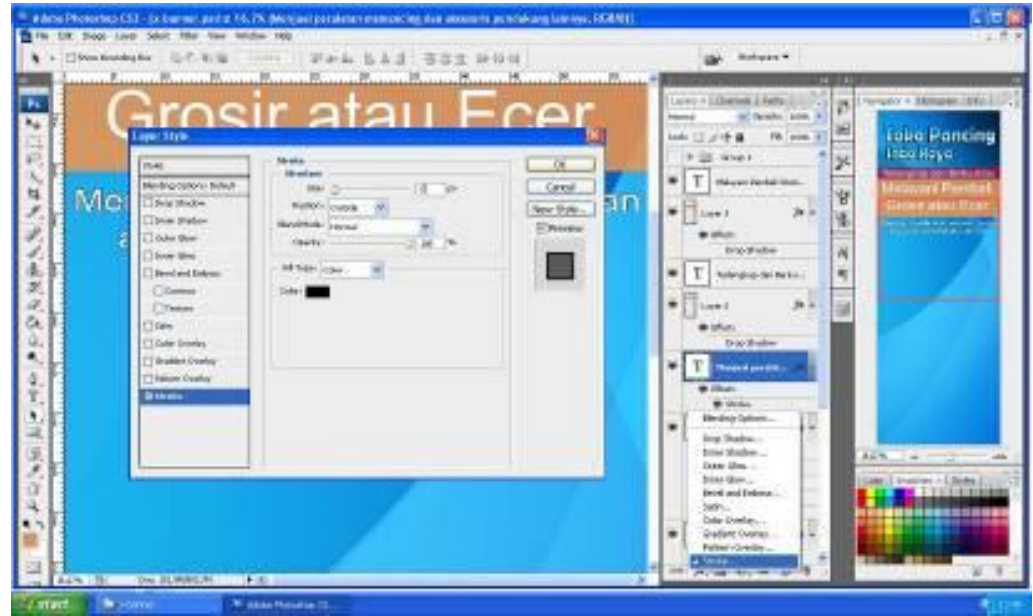

Gambar 4. 80 Memberi efek stroke.

(7). Langkah berikutnya membuat background dasar cara pembuatannya yaitu klik create a new layer untuk menambahkan layer baru lalu menggunakan Rectangular Marquee Tool lalu tarik kedalam layout sehingga membentuk persegi yang terselaksi setelah itu untuk memberi warna gunakan Paint Bucket Tool pilih warna putih sebagai warna dasarannya. 


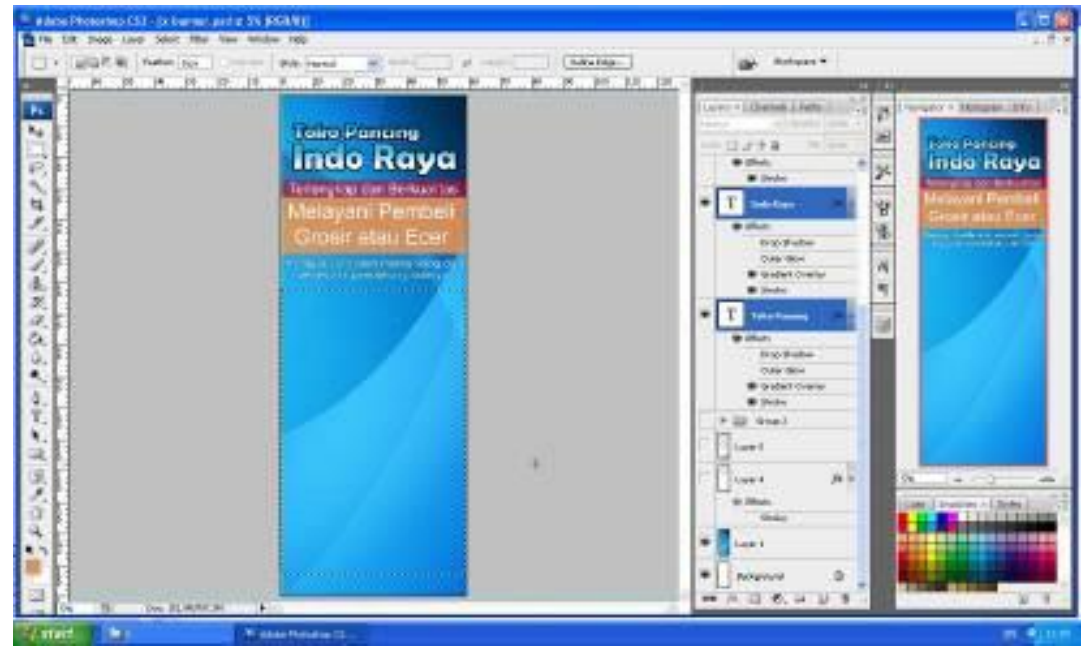

Gambar 4. 81 Membuat background dasar.

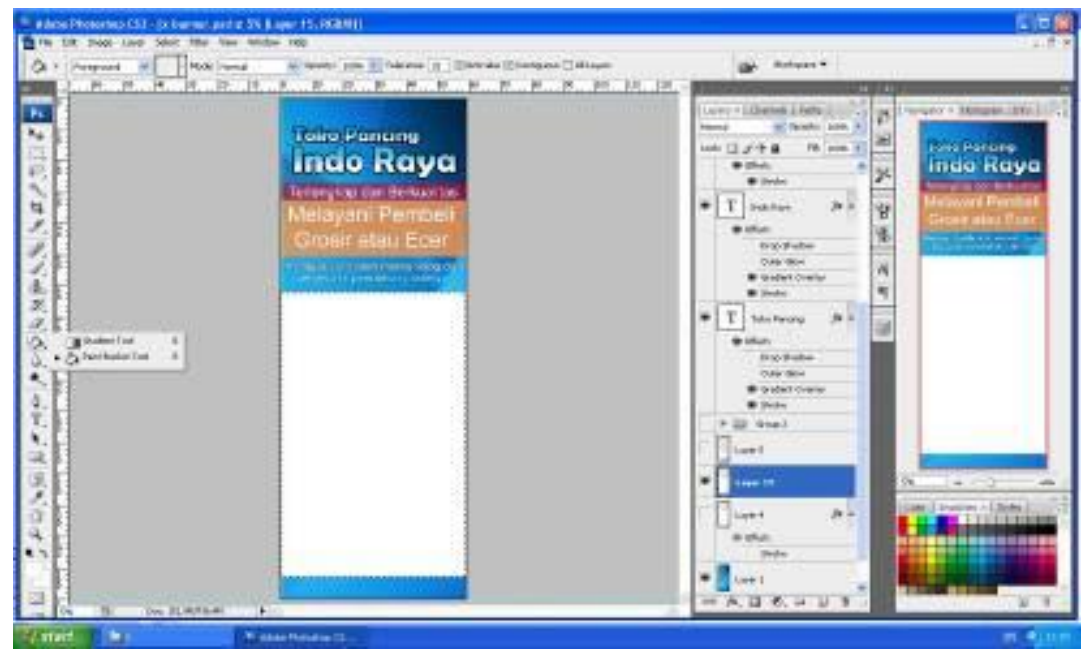

Gambar 4. 82 Memberi warna menggunakan Paint Bucket Tool.

(8). Setelah background dibuat selanjutnya pilih gambar background yang diambil dari internet lalu masukan jadi satu kedalam background dasar untuk mempercantik background agar tidak terlihat kosong klik file-open lalu pilih gambar background lalu pindahkan gambar kedalam layout dengan menggunakan move tool. 


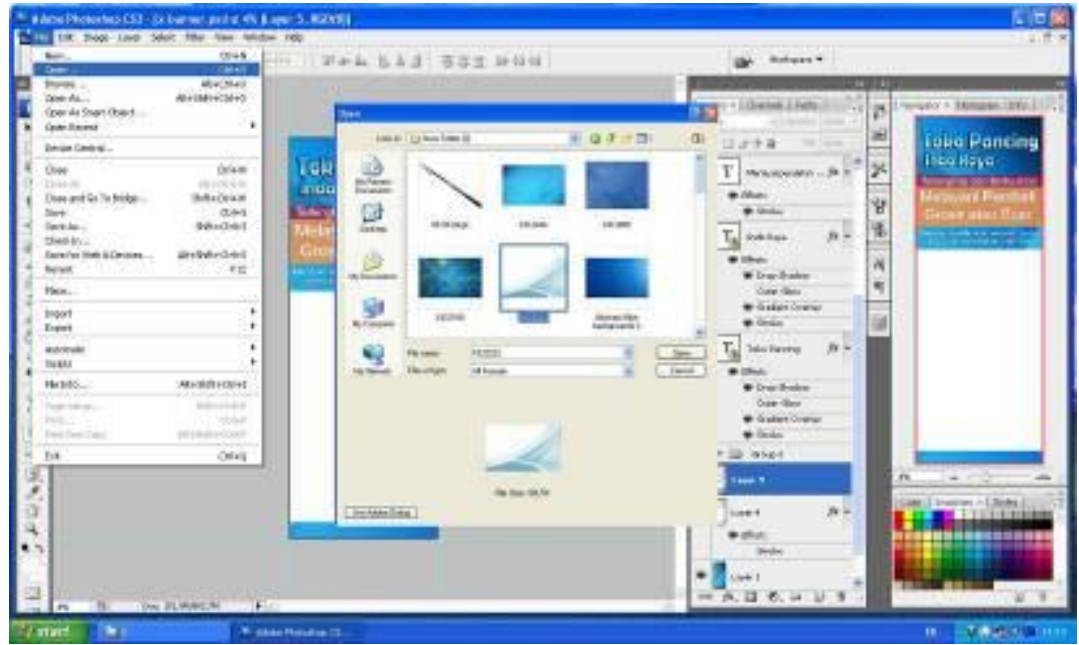

Gambar 4. 83 Langkah mengambil gambar background.

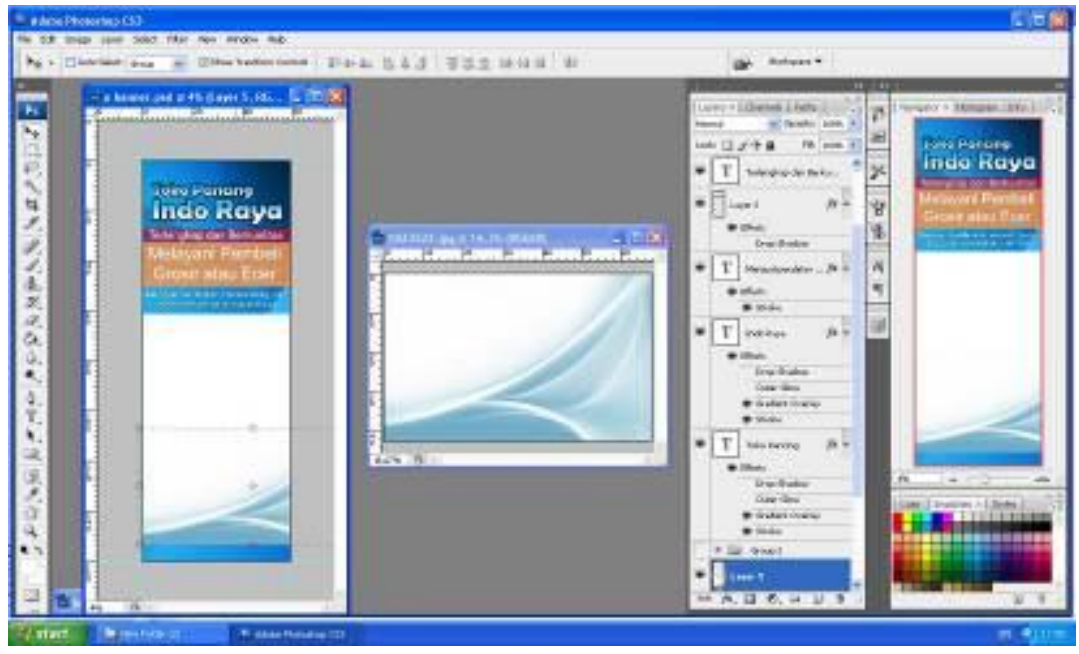

Gambar 4. 84 Langkah memindahkan gambar menggunakan move tool.

(9). Langkah selanjutnya memberi gambar produk alat - alat memancing ke dalam layout yaitu dengan mengambil gambar yang sudah dibuat sebelumnya lalu pindah kedalam layout XBenner klik file - open lalu pilih projek yang sudah dibuat lalu pindahkan gambar menggunakan move tool.

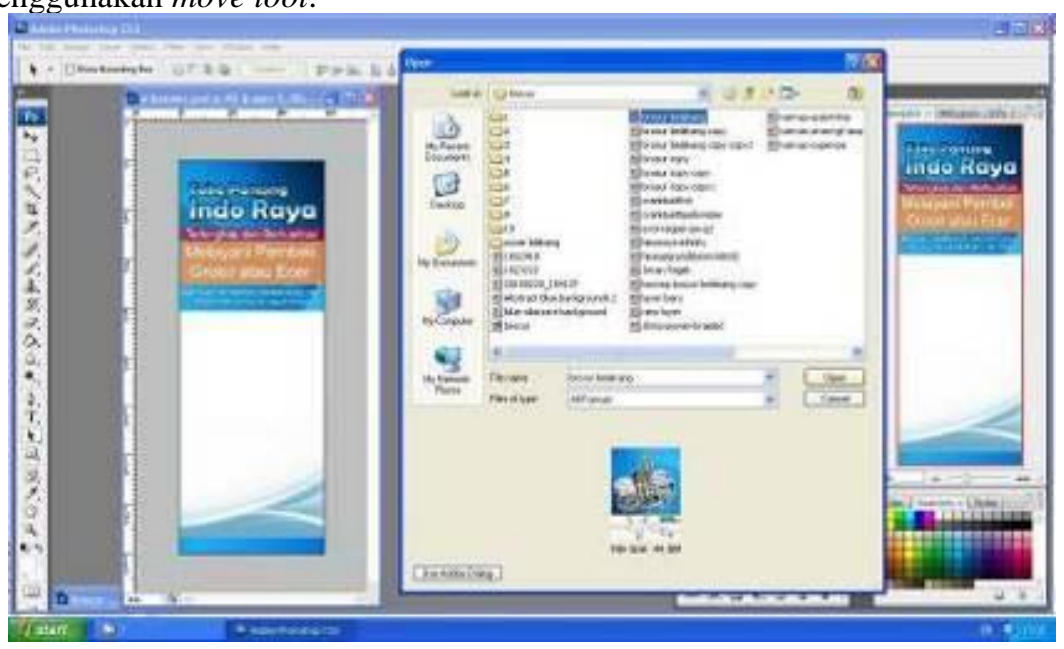

Gambar 4. 85 Membuka file gambar. 
75

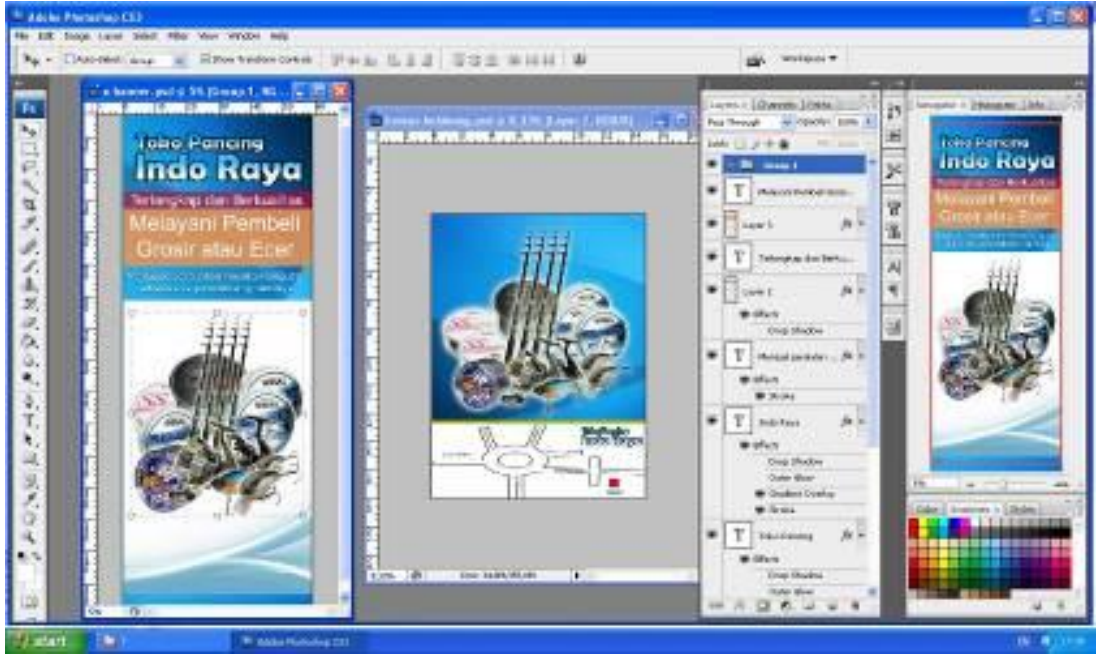

Gambar 4. 86 Memindahkan gambar yang sudah dibuat kedalam layout.

(10). Langkah terakhir yaitu menyantumkan nama - nama alat atau produk yang di jual di Toko Pancing Indo Raya dengan menggunakan Horizontal Type Tool lalu ketik text kedalam layout.

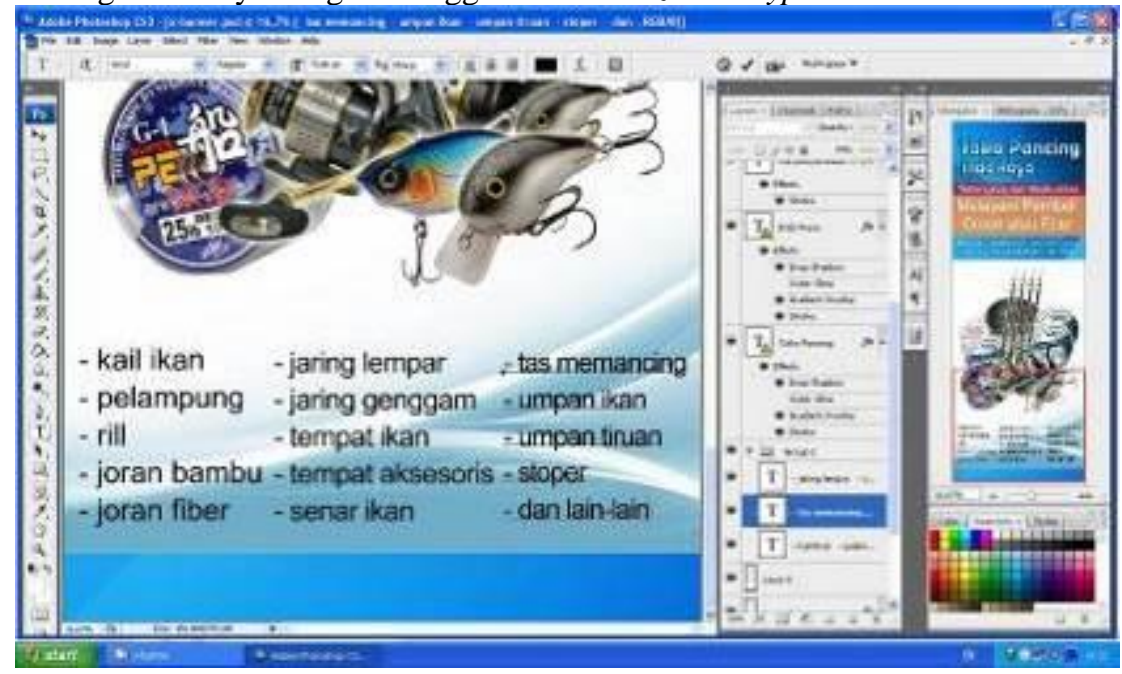

Gambar 4. 87 Memberi text nama produk yang dijual.

\section{Membuat Desain Spanduk}

a. Langkah pembuatan desain spanduk :

(1). Langkah awal yaitu open Photoshop Cs3 lalu klik file - new lalu atur layout dengan ukuran Width 400 x Height 100 dengan resolusi 72 pixel/ $\mathrm{cm}$. 


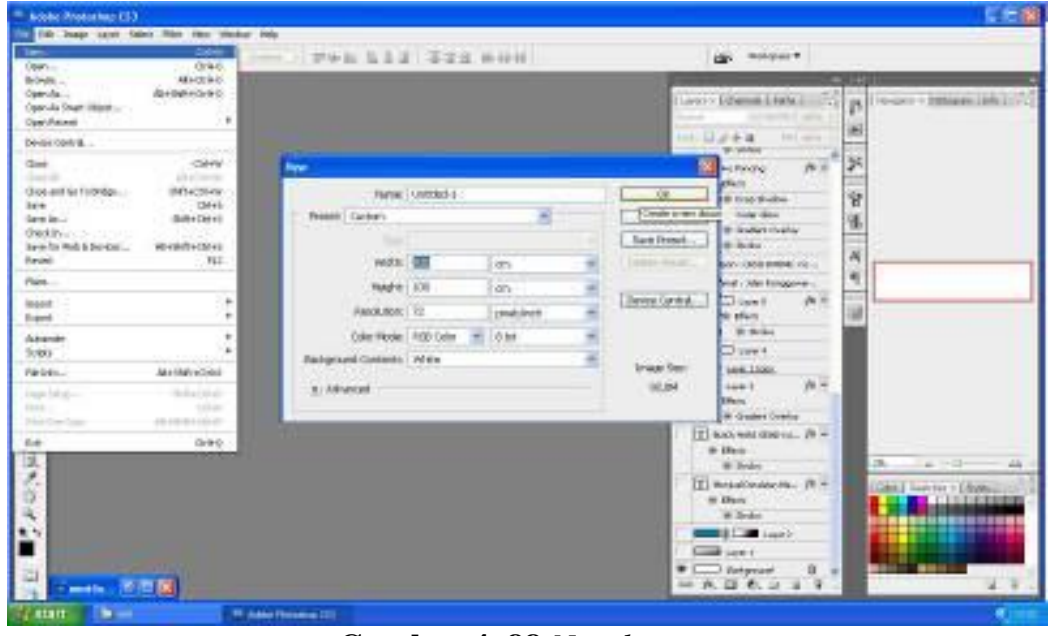

Gambar 4. 88 New layout.

(2). Selanjutnya buka gambar background dengan cara klik file - open lalu pilih file gambar background yang akan digunakan.

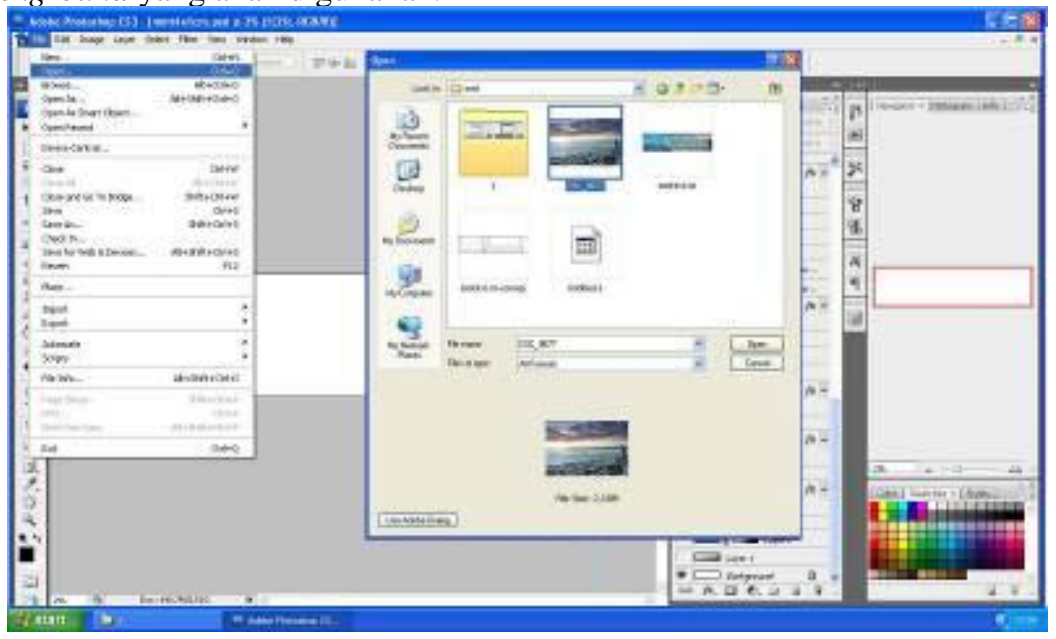

Gambar 4. 89 Membuka file background.

(3). Lalu memindahkan gambar background kedalam lembar layout dengan menggunakan move tool lalu tarik gambar background kedalam layout.

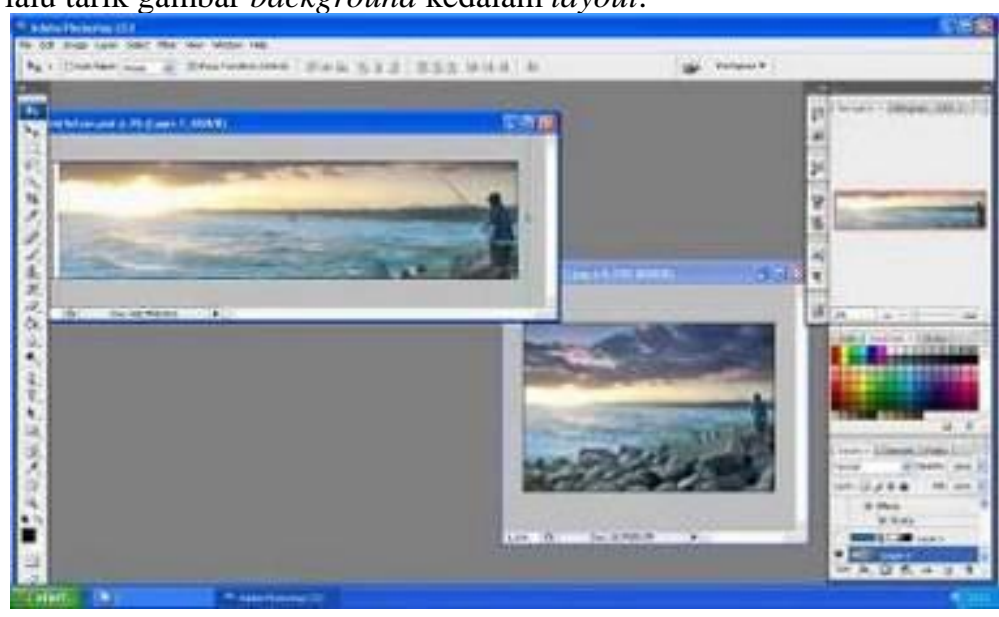

Gambar 4. 90 Memindahkan background ke dalam layout. 
77

(4). Setelah gambar dipindah ke dalam layout selanjutnya yaitu klik create a new layer untuk membuat layer baru setelah layer baru lalu beri warna biru di dalam layer yang baru dengan menggunakan paint bucket tool setelah layer diberi warna tahap selanjutnya membuat efek gradasi pada layer yang baru dengan cara klik add layer mask setelah itu klik Gradient tool dan klik pada layer dengan menarik gradient tool ke samping kanan.

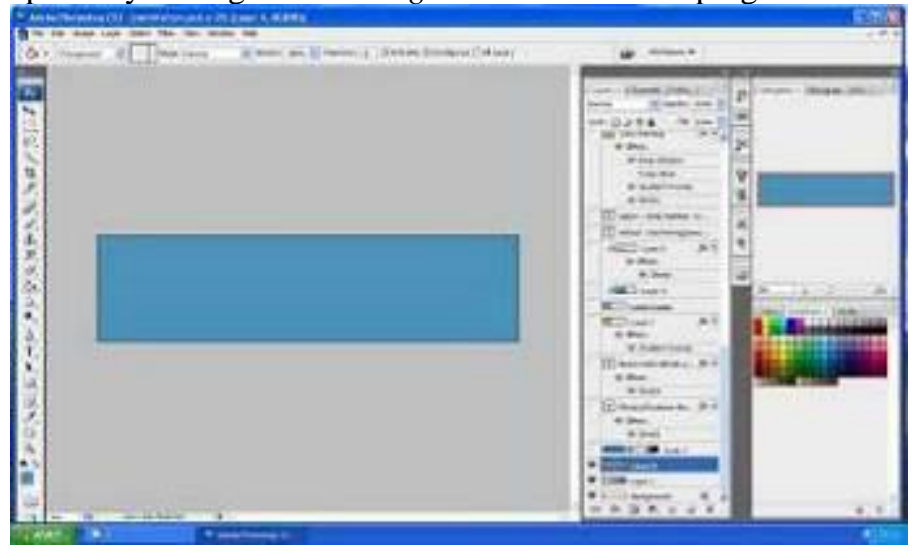

Gambar 4. 91 Memberi warna biru pada layer yang baru.

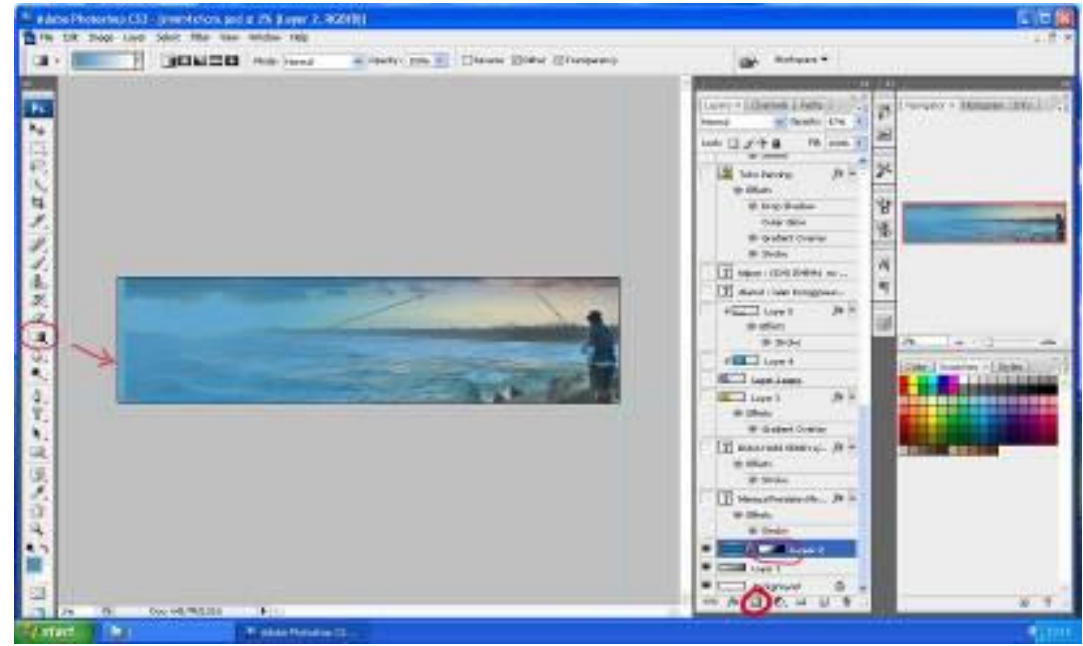

Gambar 4. 92 Memberi efek gradasi menggunakan Gradient Tool.

(5). Langkah berikutnya membuat desain nomer dua yang ada di konsep layout awal, klik Create a new layer untuk membuat layer baru lagi, lalu klik Paint bucket tool untuk memberi warna, warna yang di gunakan masih sama yaitu biru sebagai warna utama yang juga menggambarkan nuansa air laut. 


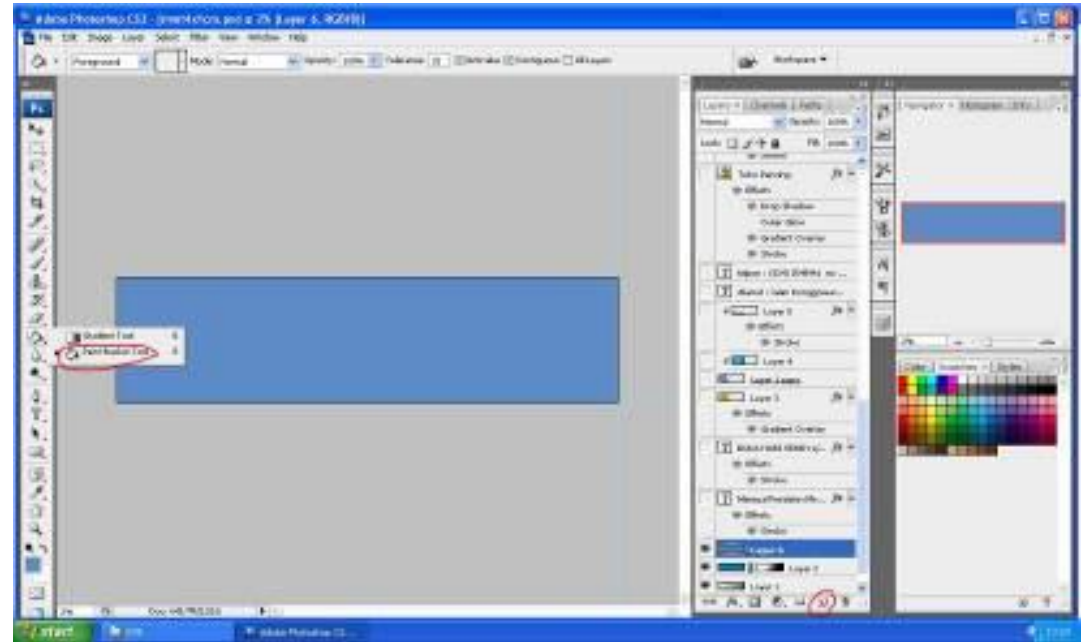

Gambar 4. 93 Membuat layer baru dan memberi warna.

(6). Selanjutnya yaitu memotong bagian dari layer dengan menggunakan Elipptical marquee tool lalu tekan dan tarik kesamping hingga membentuk lengkungan setelah terseleksi lalu klik delete pada keyboard komputer untuk memotong bagian yang terseleksi.

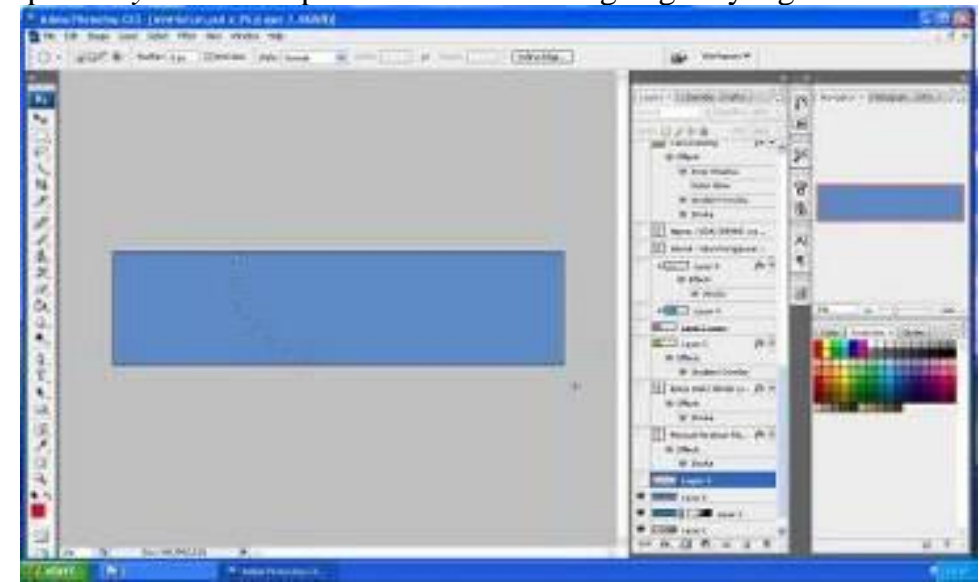

Gambar 4. 94 Layer yang sudah terseleksi.

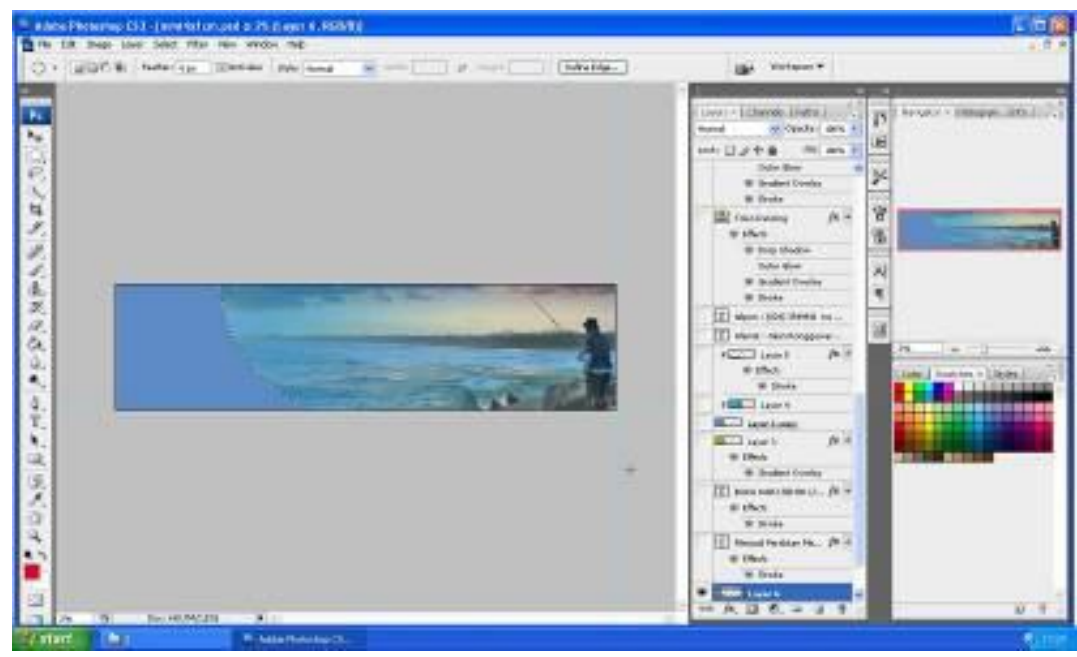

Gambar 4. 95 Sesudah bagian terpotong.

(7). Langkah berikutnya membuat garis lengkung dengan cara menduplicate layer yang sudah terpotong lalu beri warna kuning keemasan dibagian layer bawah dipilihnya warna emas pada 
garis lengkung melambangkan kehormatan bagi identitas toko. Setelah ittu geser ke samping kanan agar layer bagian bawah terlihat di layout. Setelah itu klik add a layer style - gradient overlay untuk memberi efek gradasi pada warna dan atur gradient Angle : -90 derajat, Style : Linier, lalu gradientnya geser dengan warna putih berada di tengah.

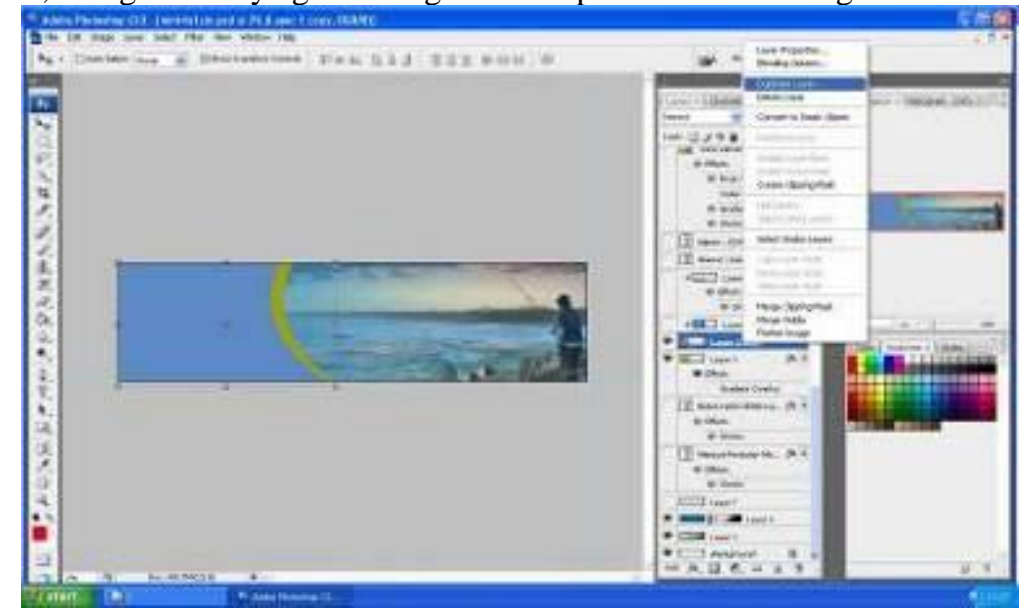

Gambar 4. 96 Membuat garis lengkung dengan menduplikat layer.

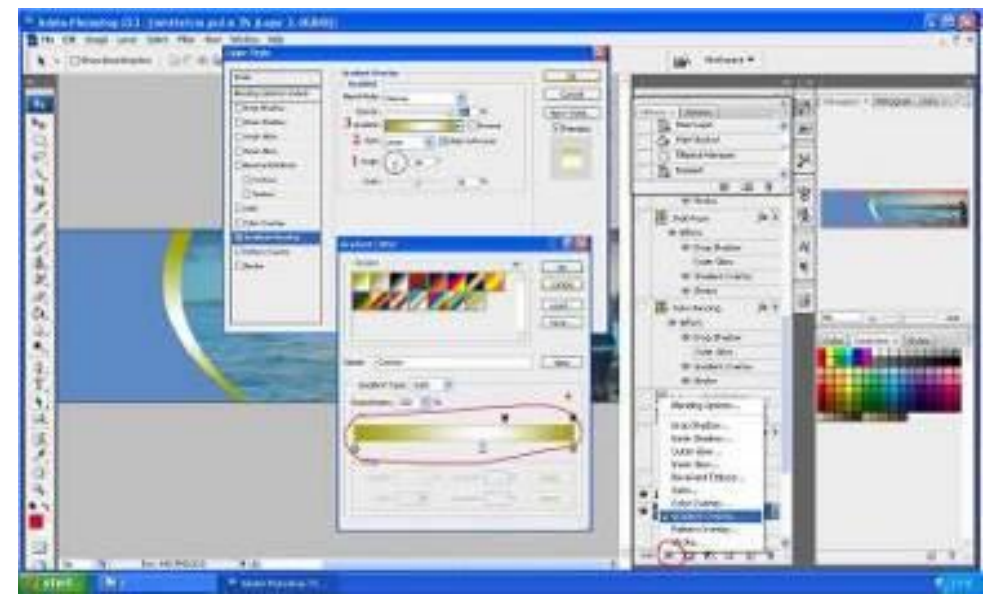

Gambar 4. 97 Langkah memberi efek Gradient overlay pada garis.

(8). Memberi background tambahan langkah pertama ambil gambar background dengan klik fileopen lalu pilih gambar background yang akan digunakan lalu klik open. Setelah membuka background lalu memindahkan background ke dalam layout dengan menarik background menggunakan Move Tool jika background sudah di dalam layout langkah berikutnya memasukan jadi satu gambar background kedalam satu layer dengan layer sebelumnya dengan menekan $\mathrm{Ctrl}+\mathrm{Alt}$ di keyboard dan klik kiri pada mouse dengan bersamaan, maka layer background menjadi satu dengan layer yang ada di bawahnya dan otomatis background akan masuk jadi satu. 


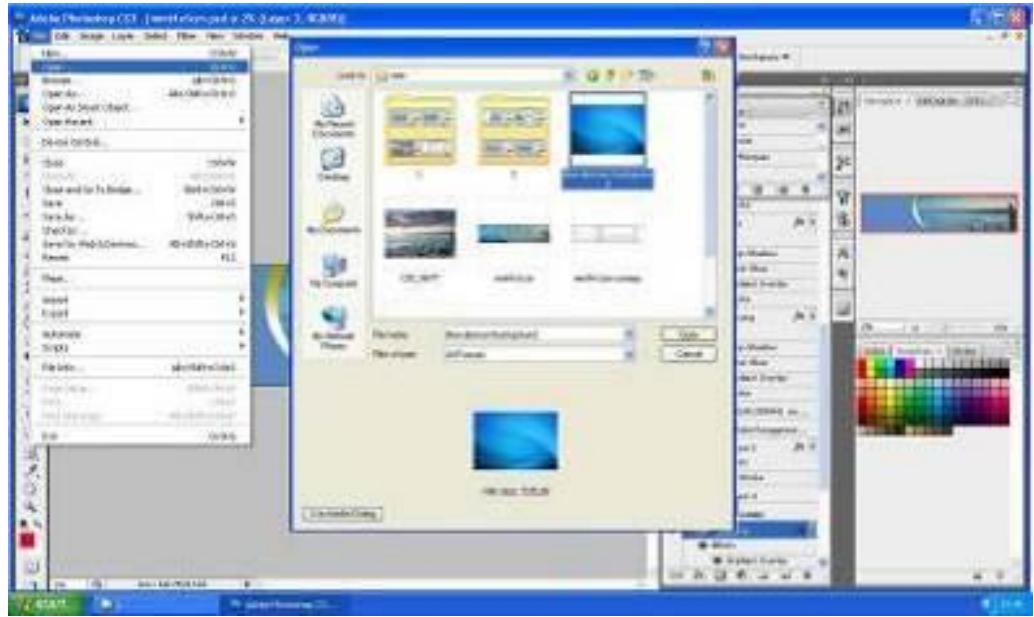

Gambar 4. 98 Langkah mengambil gambar background.

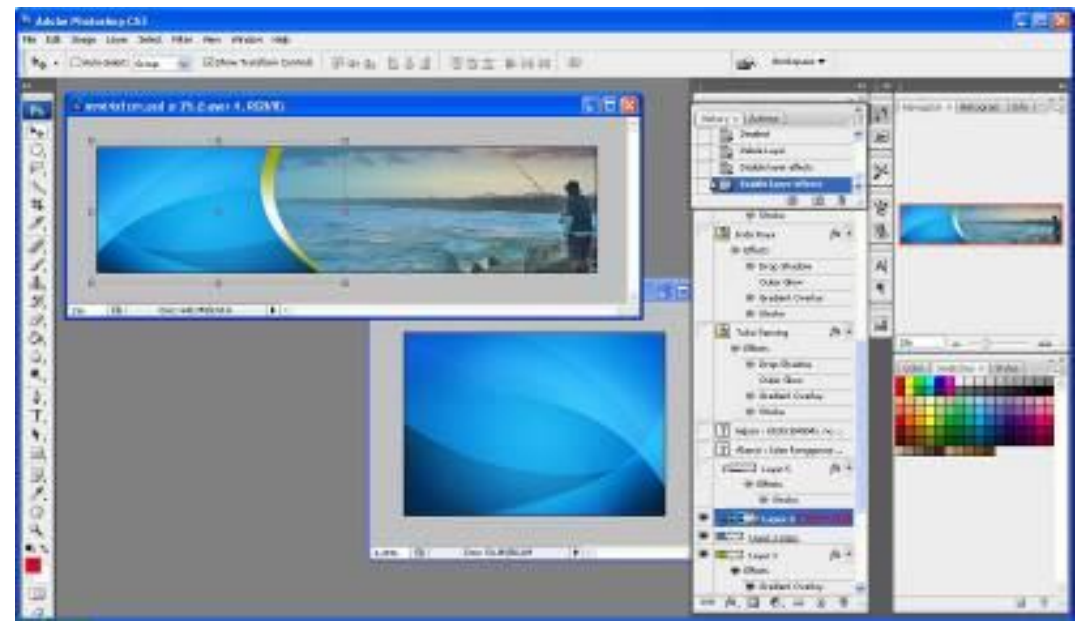

Gambar 4. 99 Langkah memasukan background.

(9). Lanjut ke tahap selanjutnya yaitu mengetik text "Terlengkap dan Berkualitas" menggunakan Horizontal Type Tool dengan tipe font Arial setelah text sudah jadi tambahkan efek Stroke, Gradiend Overlay dan Drop Shadow yang ada didalam add a layer style, atur ukuran efek untuk stroke : size : 25px, opacity : 100\%, untuk gradient overlay : gradient warna orange gradasi putih, opacity : 100\%, angle : -90 derajat, scale : 100\% dan drop shadow : opacity : $75 \%$, angle : 120 derajat, distance : $9 \mathrm{px}$, spread $: 8 \%$, size $: 5 \mathrm{px}$.

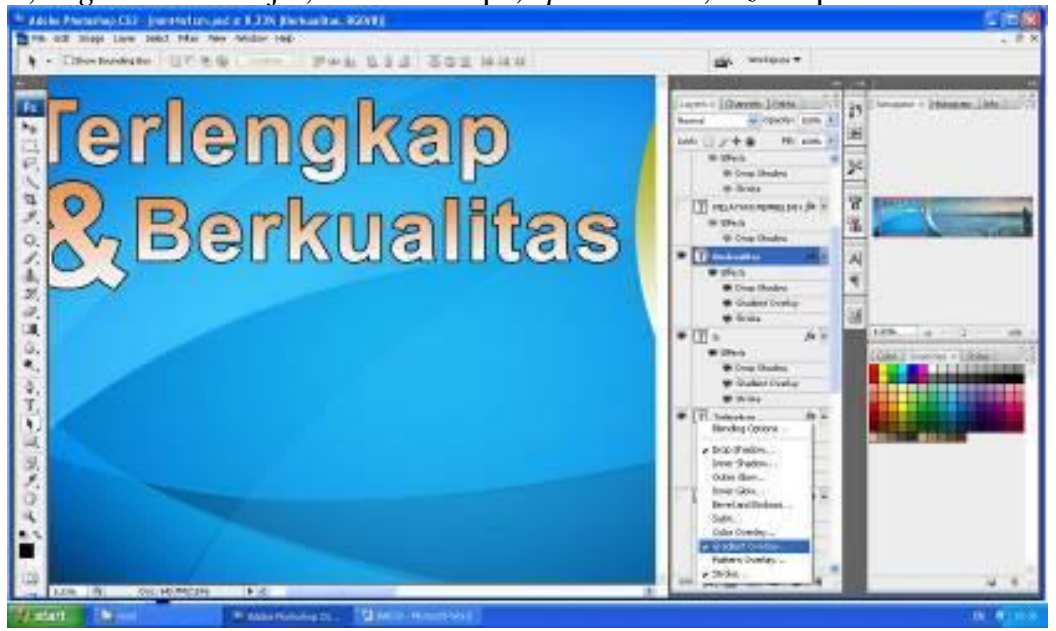

Gambar 4. 100 Efek Drop Shadow, Stroke, Gradient overlay. 
81

(10). Langkah selanjutnya mengetik text "Melayani Grosir atau Ecer" tipe font "Grosir atau Ecer" menggunakan jenis tipe font yang berbeda yaitu "Quixlay Let" agar membedakan dengan yang lain yang bertujuan agar mudah dikenal dan mudah dibaca karena informasi tersebut adalah inti dari promosi toko. Setelah text di ketik selanjutnya beri efek yang sama dengan text sebelumnya Drop shadow : opacity 75\%, Angle 120 derajat, distance 18px, spread 10\%, size $8 \mathrm{px}$.

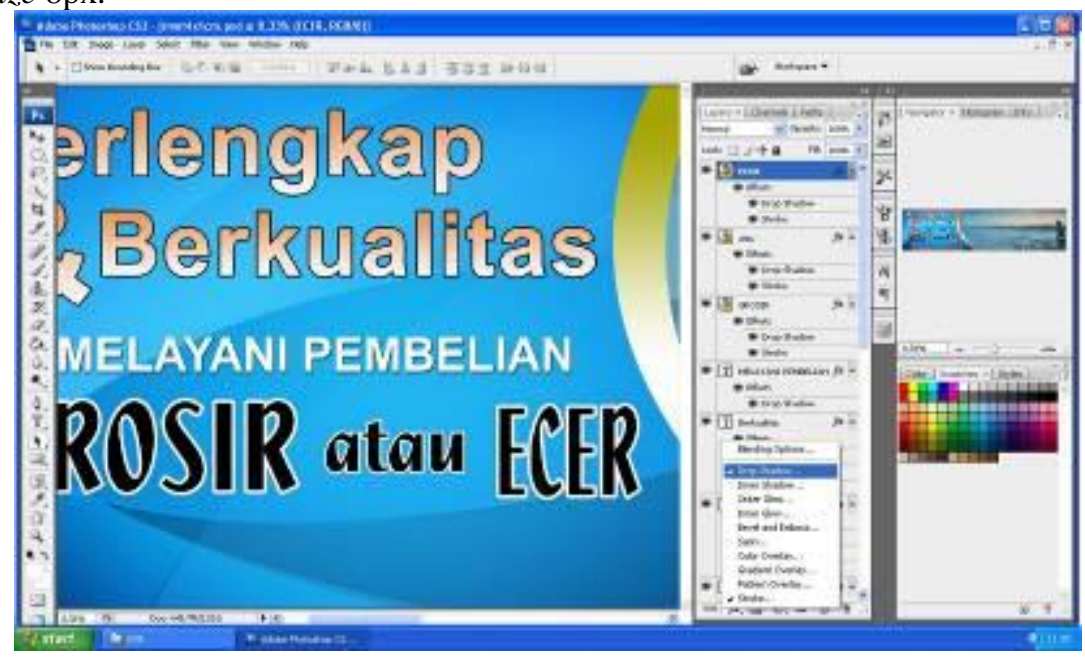

Gambar 4. 101 Memberi efek Drop shadow dan stroke pada text.

(11). Untuk selanjutnya membuat background untuk alamat toko dengan membuat persegi panjang menggunakan "Rectangular marquee tool" lalu buat new layer setelah terseleksi lalu beri warna hitam menggunakan "Paint bucket tool" beri warna hitam.

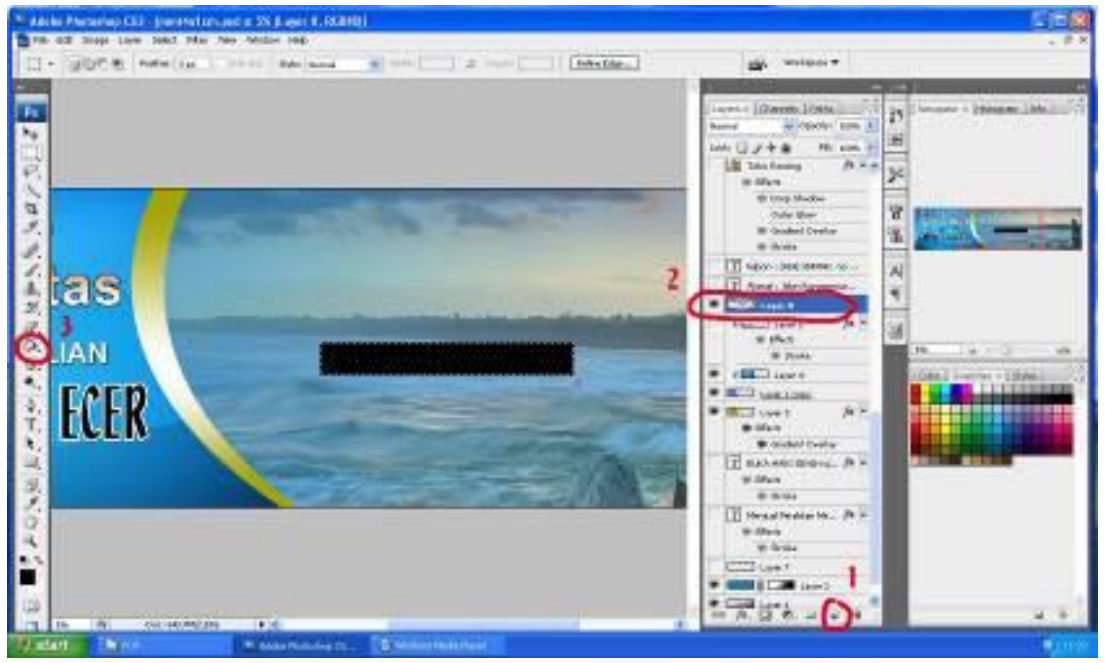

Gambar 4. 102 Membuat background.

(12). Setelah background persegi dibuat masukan jadi satu kedalam dengan layer background layer 4 dengan langkah yang sama dengan sebelumnya tekan Ctrl+Alt dan klik kiri pada mouse dengan bersamaan dan selanjutnya beri efek stroke pada background agar menimbulkan garis pada tepi backgroundnya klik add a layer style pilih stroke dan atur ukurannya Size 40px lalu ok dan ketik text alamat dan nomer telpon toko dengan menggunakan horizontal type tool. 


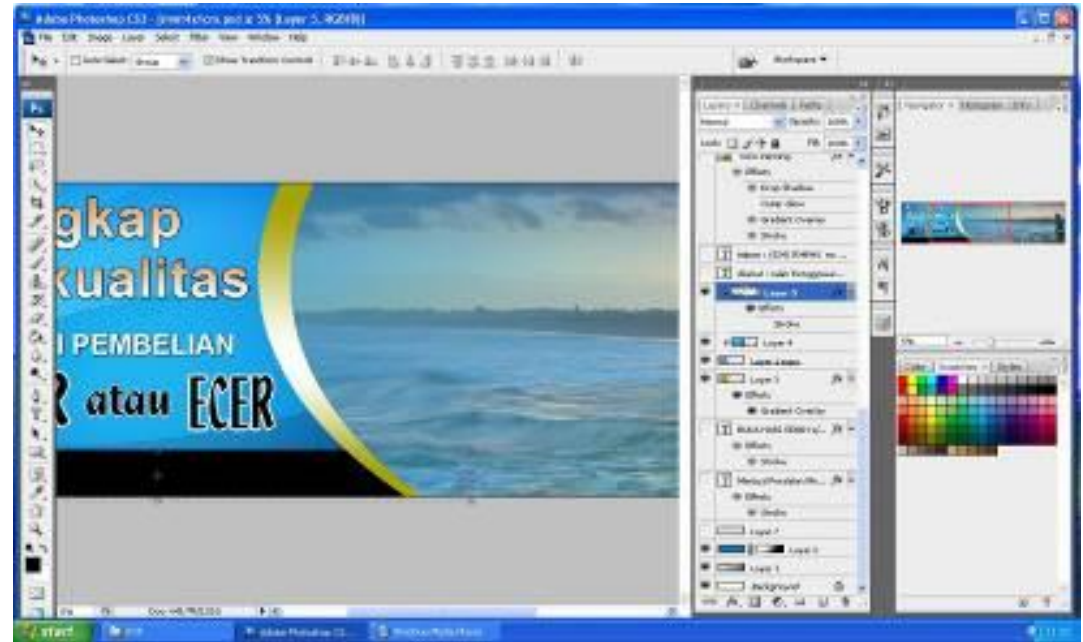

Gambar 4. 103 Memasukan jadi satu kedalam layer.

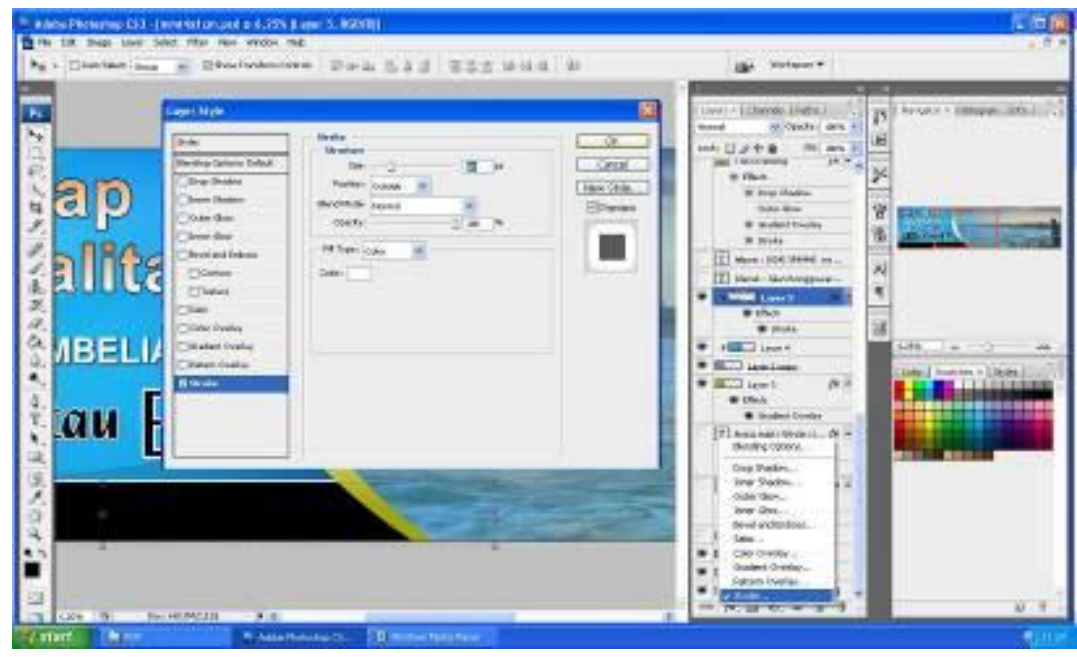

Gambar 4. 104 Memberi efek stroke.

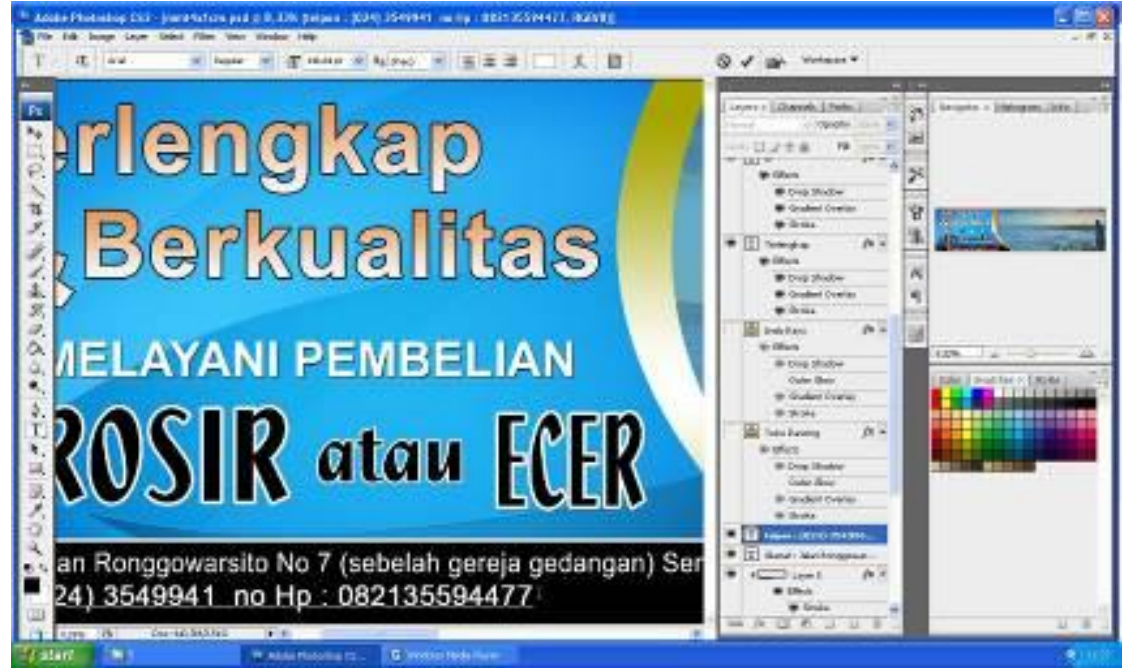

Gambar 4. 105 Menambahkan text alamat dan nomer telpon toko.

(13). Untuk tahap berikutnya menambahkan nama toko dengan menggunakan nama yang sudah dibuat atau dipakai dalam desain sebelumnya dengan memindahkan ke dalam layout desain 
spanduk klik file lalu open pilih project desain stiker lalu tarik nama toko yang ada di desain stiker menggunakan move tool dan masukan ke dalam layout spanduk.

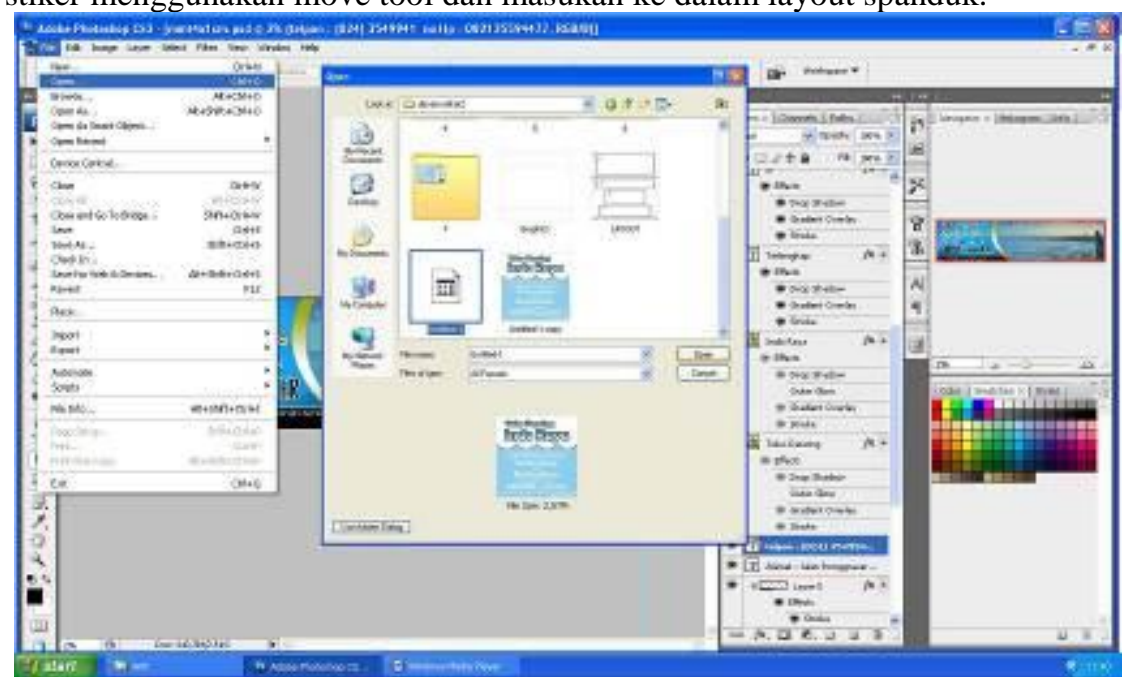

Gambar 4. 106 Membuka project desain stiker.

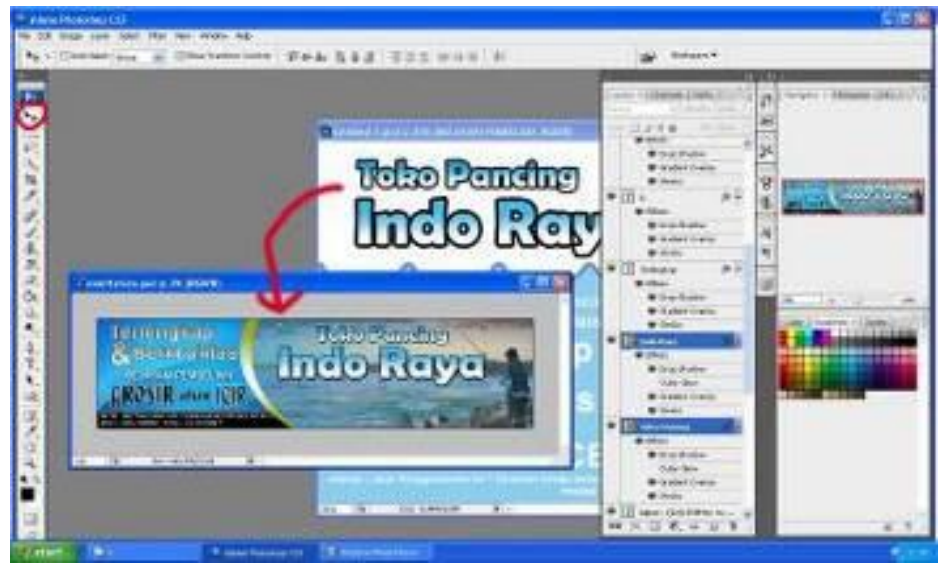

Gambar 4. 107 Memindahkan nama toko ke layout spanduk.

(14). Tahap terakhir yaitu menambahkan text "Menjual Peralatan Memancing dan Aksesoris Pendukung Lainnya" serta text jadwal jam berjualan toko dan libur berjualan toko, untuk text jadwal berjualan toko menggunakan warna kuning dipilihnya warna kuning agar terlihat mencolok sehingga orang mengetahuinya karena informasi tersebut sangatlah penting.

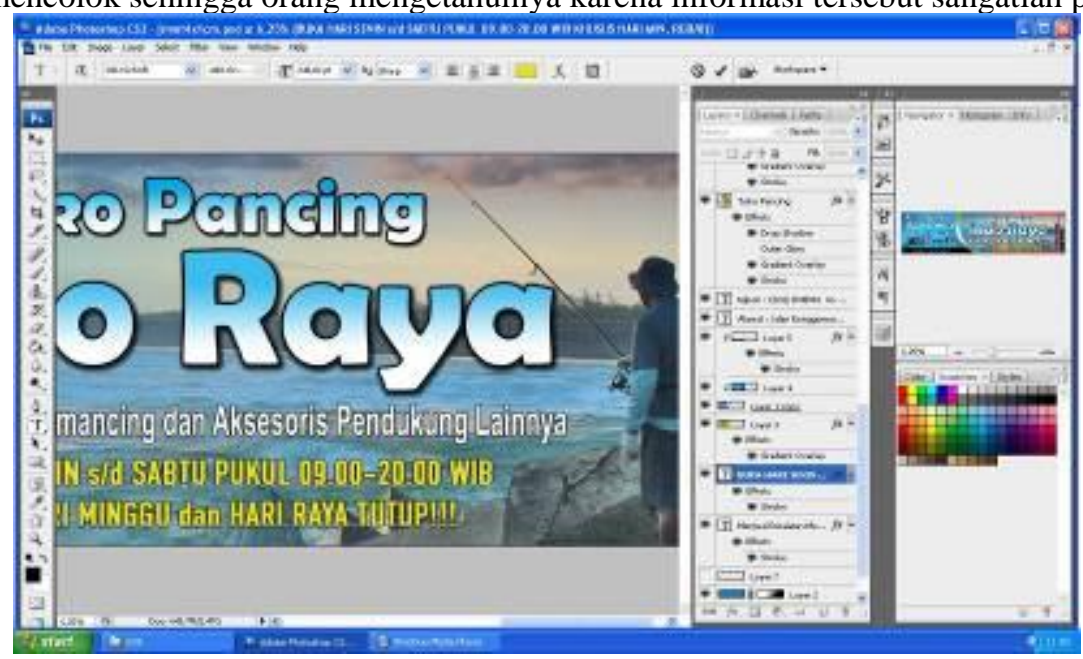

Gambar 4. 108 Text informasi jam berjualan toko. 
A. Hasil Akhir

1. Berikut ini adalah hasil akhir dari desain media cetak :

a. Stiker

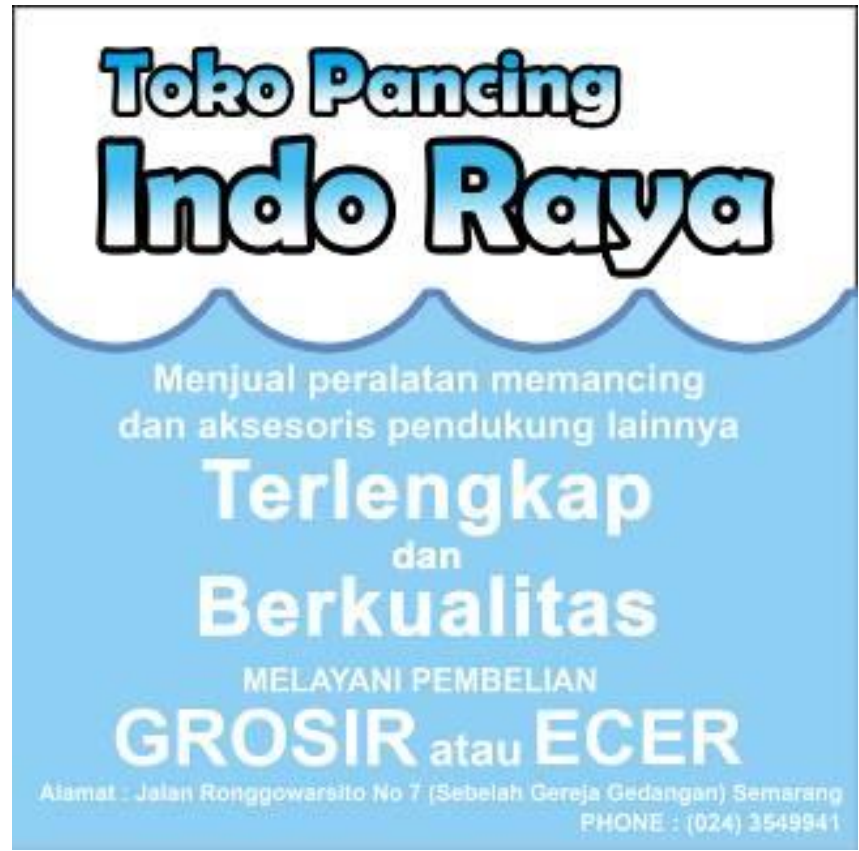

Keterangan Gambar

Gambar 4. 109 Hasil akhir desain stiker.

Untuk desain stiker dibuat sesimple mungkin dikarenakan ukuran yang tidak terlalu besar dalam tampilan yang simple namun menarik dengan menggunakan warna biru muda mengibaratkan warna air laut yang sangat jernih.

(1). Background dasar menggunakan warna putih sebagai warna dasar.

(2). Text nama toko menggunakan font BRLNSDB agar font terlihat menarik dan jelas jika dibaca untuk warna nama toko menggunakan warna biru gradasi putih yang menggambarkan gradasi warna air di laut.

(3). Background menggambarkan ilustrasi gambar yang berbentuk ombak di laut yang dibuat dari software Corel Draw X4.

(4). Untuk text yang berada di tengah menggunakan font Arial agar mudah dibaca, sedangkan ukuran text "TERLENGKAP dan BERKUALITAS, GROSIR atau ECER" menggunakan ukuran text besar supaya mudah diketahui oleh pembaca karena kata tersebut adalah inti informasi yang ingin disampaikan.

(5). Sedangkan paling bawah berisikan alamat took dan no telepon yang bias dihubungi.

b. Brosur Depan 


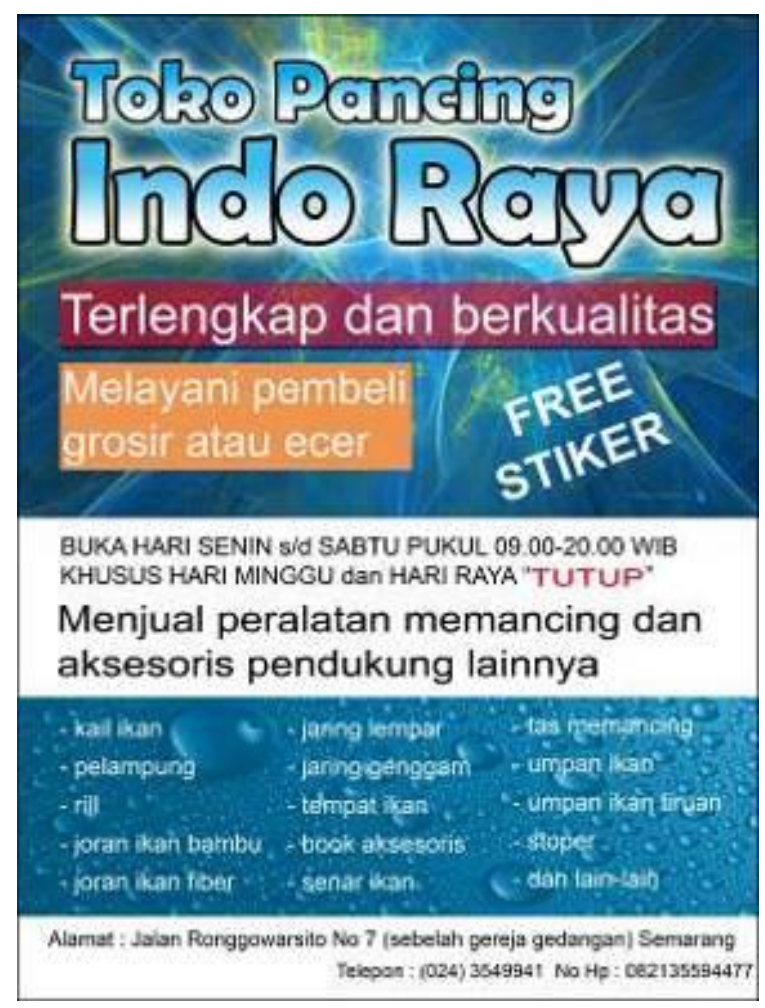

Gambar 4. 110 Hasil akhir desain brosur bagian depan.

Keterangan Gambar

Untuk desain brosur bagian depan disini tampilan brosur berbeda dengan tampilan desain stiker, karena desain brosur disini dibuat lebih ramai dengan warna - warni tampilan agar terlihat menarik tetapi untuk tampilan informasi yang disampaikan di brosur masih tetap sama dengan desain stiker hanya di brosur depan menyantumkan informasi "FREE STIKER" sebagai.

\section{Kesimpulan}

Pembuatan desain sebagai media promosi dengan media spanduk, brosur, stiker dan x-banner yang dibuat untuk Toko Pancing Indo Raya. Penulis menyimpulkan dengan dibuatnya media promosi tersebut di dapatkan keuntungan yaitu :

(1) Dengan adanya media promosi seperti spanduk, brosur, stiker, $\mathrm{x}$-banner di Toko Pancing Indo Raya diharapkan bisa dikenal oleh masyarakat dari segi tempat berjualan dan barang atau produk yang dijual di Toko Pancing Indo Raya. Sehingga dapat menambah atau meningkatkan jumlah konsumen.

(2) Promosi seperti spanduk, brosur, stiker, x-banner sebagai media promosi dapat dijadikan media informasi bagi pelanggan untuk mengetahui barang apa saja yang dijual dan informasi tentang promosi terbaru dari Toko Pancing Indo Raya.

\section{DAFTAR PUSTAKA}

[1] Athenk, Arts, 2012; "Efek-efek Terbaik Corel Draw dan Photoshop",Yogyakarta : Citra Media Pustaka,.

[2] Hasto, Prayoga, 2014; “Corel Draw Untk Bisnis”, Jakarta : PT.Elex Media Komputindo,.

[3] Henry, Mintzberg, 1998; "Strategi Menurut Para Ahli", [http://www.apapengertianahli.com/2014/12/pengertian-strategi-menurut-beberapa-ahli.html\#]

[4] Hendratman, Hendi, 2014; "Graphic Design”, Bandung : Informatika,.

[5] Ibnu, Teguh, Wibowo, 2013; "Belajar Desain Grafis”, Yogyakarta : Buku Pintar,.

[6] Jogiyanto, H, m , 1991; "Hiburan dan Teknik Belajar Pemrograman Vicual Basic" ,[http://rumohkuta.blogspot.com/2013/02/pengertian-perancangan.html] 
[7] Kristiawan, Soegijanto, 2010; "Bikin Promosi Kreatif Dengan Corel Draw",

[8] Yogyakarta : Multicom,.

[9] Rakhmat, Supriyanto, 2010; "Desain Komunikasi Visual-Teori dan Aplikasi”, Yogyakarta : C.V. Andi Offset,.

[10] Rinaldi, Munir, 2004; "Pengolahan Citra Digital”, Bandung : Informatika Bandung,.

[11] Tjiptono, 2001; "Strategi Promosi Penjualan | Berbagi Pengetahuan", [https://lindanoer.wordpress.com/2014/01/08/strategi-promosi-penjualan/]

[12] Lasa. 2007. Manajemen Perpustakaan Sekolah. Yogyakarta : Pinus.

[13] M. Shalahuddin,2010, Modul pembelajaran pemrograman berorientasi objeck dengan

[14] bahasa pemrograman C++,PHP,DAN JAVA,Modula.

[15] Privida Kristiono, 2007. Pemrograman Database Tingkat Lanjut dengan VB6, buku ke

[16] satu,PT Elex Media Komputindo, Jakarta.

[17] Sutarno NS. 2006. Perpustakaan dan Masyarakat. Jakarta: Sagung Seto. 